\title{
IMPACT OF ARMED CONFLICT ON AFGHAN CHILDREN
}

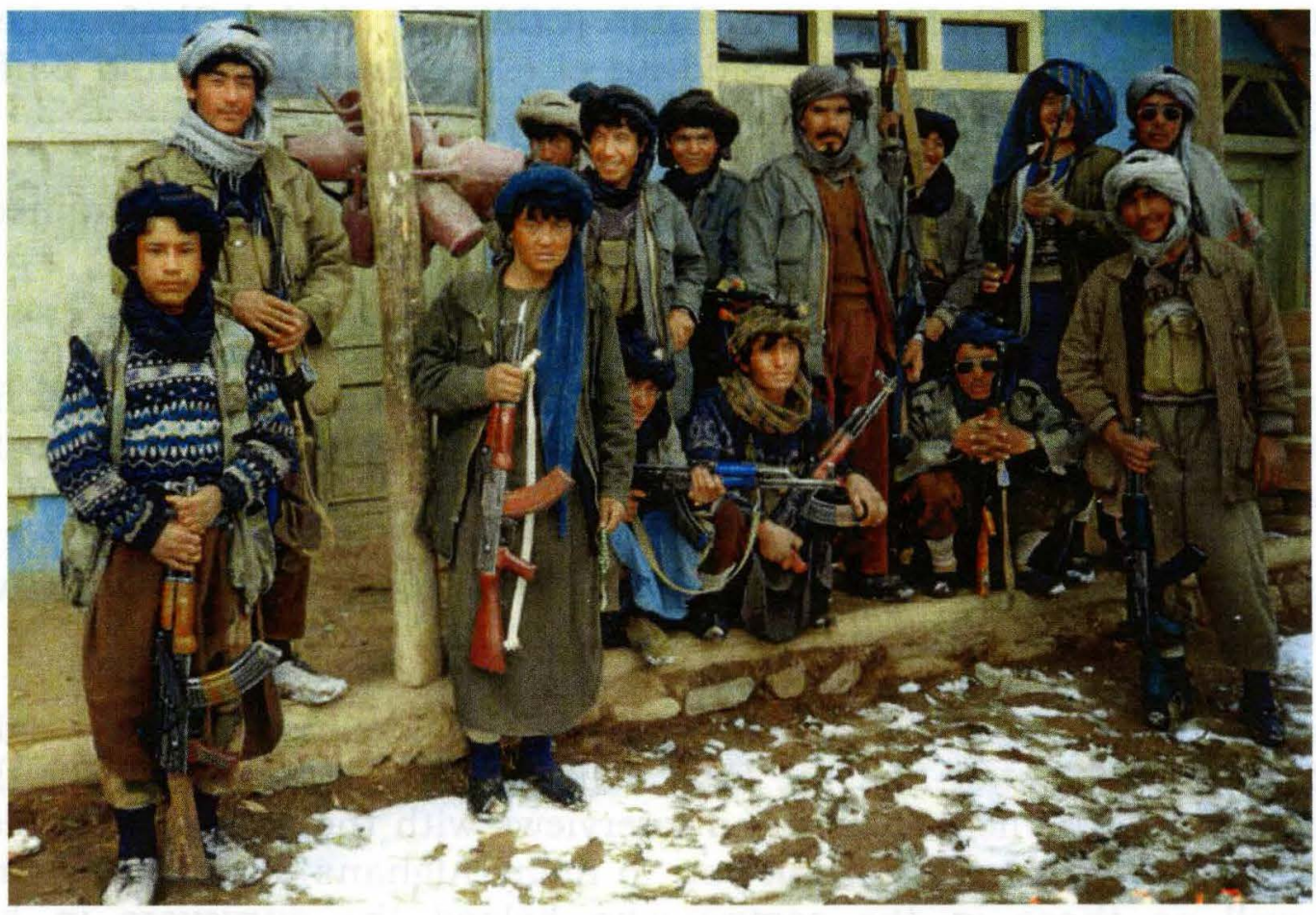

Save the Children Sweden

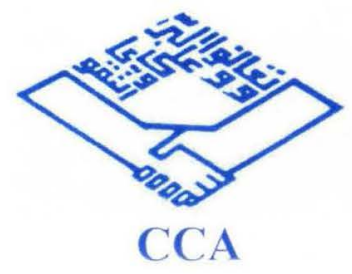

unicef (3) 


\section{Acknowledgements}

Thanks to everyone who has contributed to this study and report. Professor Hassanyar from the Cooperation Center for Afghanistan (CCA) initiated and coordinated the study and staff of Save the Children Sweden (SCS) and staff of Cooperation Center conducted the field research for Afghanistan (CCA).

The research team consisted of: Mr. Sadaqat Shah Roghani (SCS), Ms. Afifa Azim (SCS) Ms. Sediqa Shahbaz (SCS), Mr. Fazel (CCA), Mr. Sayed Jaffar Nastoh (CCA), Ms. Asma Habib (CCA), Mr. Abdul Ghafour Lewal (CCA), Mr. Ehsan (CCA), Mr. Said Aqeel (CCA) and Mr. Hamid Saffwat (CCA).

Before the study started all surveyors and data collectors were trained in CRC by the SCS staff and Ms Marzia Mina from CCA.

Dr A.W. Najimi followed up the study after the departure of Mr. Hassanyar. Mr. Najimi guided the data analysis and wrote the draft final report and Ms. Angela Coleridge developed the report further into this final report

Unicef provided joint funds together with Save the Children Sweden who also assisted technically in the study.

Last but not least thanks to the office of the commissioner for Afghan Refugees in Pakistan and the CAR staff in the refugee camps for their assistance in the field survey and interviews with the Afghan refugees in NWFP and Quetta. Also thank you to many Afghans inside the country as well as those in the camps who helped the surveyors in hard circumstances- even when there was security risks for the surveyors and their guides.

Peshawar, September 2003

Lisa Lundgren

Country Representative

Pakistan/Afghanistan

Save the Children Sweden 


\section{List of Contents}

1. INTRODUCTION

1.1 Critical Issues concerning children as soldiers

1.2 Justification for undertaking this research

1.3 The Convention on the Rights of the Child and Optional Protocols

1.4 Background to the war in Afghanistan and its impact on recruitment and child soldiers

1.5 Report Organisation

\section{RESEARCH RATIONALE AND DESIGN}

2.1. Objectives

2.2 Research Methodology

2.2.1 Field Research Activities

2.2.2. Timing and duration of the study

2.2.3. Data Collection

2.2.4. Data Analysis

2.3. Preparation of the Report

2.4. Division of Responsibilities

2.5 Constraints

\section{PRESENTATION OF FINDINGS}

3.1 Data from former child soldiers

3.1.1 Age groupings of the child soldiers interviewed

3.1.2 Numbers of child soldiers during different periods of the war

3.1.2.1 In refugee camps

3.1.2.2 Inside Afghanistan

3.1.3 The reasons why children became soldiers

3.1.3.1 In refugee camps

3.1.3.2 Inside Afghanistan

3.1.4 Psychological impact of fighting on child soldiers

3.1.4.1 In refugee camps

3.1.4.2 Inside Afghanistan

3.1.5 Addiction to drugs

3.2 Data from other target groups

3.2.1 Families of former child soldiers

3.2.2 Neighbours of former child soldiers

3.2.3 Mujahedin commanders

3.2.4 Former army officers

3.2.5 Doctors

3.2.6 Former teachers 
4 FURTHER ANALYSIS AND DISCUSSION

4.1 The reasons why children joined armed groups,

4.2 Experiences and problems of being a child soldier

4.3 Psychological impact of fighting on child soldiers

\section{CONCLUSIONS AND RECOMMENDATIONS}

5.1 How children living in the refugee villages ( camps) and in Afghanistan are psychologically affected by war

5.2.How the Afghan children and the families deal with the experiences from the war, both in the refugee villages and inside Afghanistan

5.3.The mechanisms and push factors involved in recruitment of child soldiers and the extent of the problems in Afghanistan

5.4 Recommended strategies and programmes to work with children who are psychologically affected by war.

\section{APPENDIX}

Supportive Texts 


\subsection{Critical Issues concerning children as soldiers}

'Children are today used to fight in armed conflict in more than 30 conflicts across the world. Boys and girls are abducted, forced, or persuaded to join up, often in brutal circumstances and for many, becoming a soldier is a simple matter of survival. These children are often from countries fighting internal wars, where poverty and exclusion merge with political ambition and pursuit of power by violent means, and where civilians become victims and sometimes perpetrators of atrocities. "

The impact of armed conflict on children has only recently been brought to the attention of the international community. Increased awareness and concern for these children was to a great extent due to the study carried out and submitted to the UN General Assembly by Ms. Graca Machel in $1996^{2}$. However, if the international community is to take effective action, there is an urgent need for their pledges to have practical impact on these children's lives. Agencies and governments must work together with a shared understanding of child soldiers and the influences that have shaped them.

Today, there are as many as 300,000 children under the age of 18 years old, serving in government forces or armed rebel groups around the world. Some are as young as eight years old. These children and young people need to play a full role in activities aimed at preventing their military recruitment, release, demobilisation and reintegration. Studies that can draw on insights of child soldiers themselves are a starting place for this participation.

The release and demobilisation of child soldiers is an on-going initiative, based on humanitarian consideration and designed to meet the uniqueness of each situation. To achieve this, there needs to be a thorough understanding of regional recruitment practices, the experiences of children caught up in armed conflict, and the impact it has had on them.

Successful prevention and reintegration of former child soldiers depends on long-term commitment at local levels.... Agencies need to work closely with families and

\footnotetext{
'McConnan, I and Uppard S ( 2001) Children Not Soldiers. Save the Children, Page xiii

${ }^{2}$ Machel, G ( 1996) Impact of Armed Conflict on Children. Report of the expert on the Sectretary General, Ms. Graca Machel, submitted pursuant to General Assembly Resolution 48/157
} 
communities to develop sustainable strategies for child protection and to understand why they had been unable to prevent recruitment. A major factor in recruitment of children is poverty. It has been shown to work in numerous subtle ways to expose particular children to recruiting influences. If long-term protection is to be achieved then the causes of poverty must be understood, and viable alternatives offered for a livelihood.

This research is set within these current concerns. It seeks to address the need for a shared understanding of the lives of child soldiers and the regional recruitment factors, in order to inform planning on their demobilisation and reintegration. It also seeks to deepen understanding of the factors that have weakened the protective shield of families and communities, and demonstrate the subtle interplay of factors which make children more vulnerable. By collecting extensive data from former child soldiers it has respected the need for child participation.

\subsection{Justification for undertaking this research}

An Asia-Pacific Conference on the use of Children as Soldiers was held in Kathmandu, Nepal from $15^{\text {th }}$ to $18^{\text {th }}$ May, 2000, arranged by the Coalition to Stop the Use of Child Soldiers. As an outcome of this Conference, a meeting between the representatives of Save the Children Sweden, UNICEF, Afghanistan Country Office and Cooperation Centre for Afghanistan (CCA) a (then) Pakistan based Afghan Human Rights Organization took place in which the three organizations agreed to undertake a research study on the "Impact of Armed Conflict on Afghan Children". CCA was identified as the implementing organization and both UNICEF and Save the Children Sweden were identified as the funding and technical assistance partners.

This research aimed to explore the mechanisms and push factors involved in recruitment of child soldiers and the extent of the problem in Afghanistan. Its purpose was to inform programmes involved with reintegration of young people who have been involved with armed groups. It took place during the last months of the Taliban regime. Since then the Taliban have been removed from power and an Interim Government has been elected.

A major task of the new government and its international supporters is to disarm the different militant factions and plan for the demobilisation and reintegration of its militia. There is therefore an opportunity to work with government in a comprehensive program with former child soldiers. Thus this research has become of increased significance since it was undertaken in 2000-2001. A programme is already being initiated by SC-S for the reintegration of war-affected adolescents in Nangarhar Province which will need to build on its findings. 


\subsection{The Convention on the Rights of the Child and Optional Protocols}

This research seeks to address the issues contained in the UN Convention on the Rights of the Child (CRC -1989); together with the ILO Convention 182 on the worst forms of child labour. This specifically includes forced or compulsory recruitment of children for use in armed conflicts. It also addresses the Optional Protocols and UN Security Council Resolutions 1261 and 1314 on children in armed conflict.

The CRC provides the core principles for protecting the rights of all children in armed conflict, not just those in fighting forces. These principles should inform all work with children, in order to promote the best interests of the child. This includes the importance of family unity, the need for children and young people to be listened to, and for their opinions and wishes to be given due weight.

Though States have the main responsibility for implementing the CRC through their national laws, agencies with specialist knowledge of the CRC can work with government to. develop capacity in key areas, especially protection in armed conflict (Article 38), protection of children without families (Article 20) and recovery and social reintegration (Article 39)

The CRC defines a child as 'every human being below the age of eighteen years unless, under the law applicable to the child, majority is attained earlier' (Article 1 CRC, 1989). The international community is moving towards a ban on compulsory recruitment under 18 , but individual states can set their own minimum age for voluntary recruitment. The CRC stimulates this must be over 15 . Though it otherwise defines a child as any person under 18 .

A new Optional Protocol to the CRC on Involvement of Children in Armed Conflict was adopted by consensus by the UN General Assembly in May 2000. It raises the minimum age for direct participation in hostilities, for compulsory recruitment, and any recruitment by non-governmental armed groups from 15 to 18 years. It also calls on states to raise the minimum age and introduce strict safeguards for any voluntary military recruitment under 18 .

Efforts to promote 'the physical and psychological recovery and social reintegration' of children 'in an environment which fosters the health, self respect and dignity of the child' is covered in Article 39. Article 4(30) of the Additional Protocol II to the 1949 Geneva Convention states that children (under 15) who have 'taken part in hostilities' should not be excluded in the provision of care due to all children affected by armed conflict. These include family reunification and education. 


\subsection{Background to the war in Afghanistan and its impact on recruitment and child soldiers.}

The recent war in Afghanistan was triggered when the soviet-backed regime came into power in 1978, and intensified when the Russian army invaded in December 1979. From 1978 to 1992, forces resisting this regime and Russian occupation fought the war as a Jihad. This was a holy war in defence of their country, religion and values. When the Russians were forced to withdraw in 1992, competing political parties grappled for supremacy and the country slid into nine years of civil war. The US invasion of Afghanistan in 2001 brought this to an end and set in place the present Interim Government.

The official census in 1979, gave the population of Afghanistan as 2,110,044 households. The average household had seven members, making the total population 14,770,308. Using these figures and a $2 \%$ annual increase over 21 years of natural population growth, the population at the time of this research can be estimated at $21,000,000$. This would mean around $13,650,000$ under 18 years old.

During the soviet-backed regime, the official age for military service was between 18 and 40 years old, but all the warring factions, both government and opposition, have recruited children under 18 years old. Child soldiers have formed a significant proportion of the armed forces in the Afghan war. Although there are no reliable figures, former army officers and Mujahedin commanders estimate that more than 250,000 children under the age of 18 have actively participated in armed conflict. Estimates vary from $20 \%-30 \%$.

The Islamic State of Afghanistan ratified the CRC in 1994, however, when the Taliban regime came to power, they claimed to have annulled this in a general revocation of all international agreements which the previous Afghan government had signed or ratified.

\section{The Military, and the stages of the war}

\section{National Recruitment Legislation}

The constitutions of Afghanistan, adopted by King Amanullah in 1924, King Nadir Shah in 1931, King Zaher Shah in 1964 and President Daud Khan in 1977, included a Nezam Nama-i-Askari (Military Conscription Code) that set the age for conscription at 22 with military service lasting for two years. The graduates of high schools had to spend two years as soldiers, and university graduates served one year with the military, six months in training and six months as petty officer in a garrison.

In the beginning of the 1980 s, however, the soviet communist government lowered the conscription age from 22 to 19 and then 18 and even to 17 years during the state of emergency. The length of military service was extended from two years to three. After the proclamation of emergency law, the government collected schoolboys and youngsters from the street, even below the age of 15 . The mobile military groups commissioned to

\footnotetext{
*Note: The present government has confirmed its commitment to previously signed international conventions. 24 September 2003 Afghanistan signed also the Optional Protocol to the CRC on Involvement of Children in Armed Conflict.
} 
collect youngsters were forcibly changing the ages of the boys on their ID cards to 18 years old, or would demand a large sum of money for their release. This indiscriminate recruitment was caused by the shortage of soldiers.

\section{Chronology of the War}

A chronology of the war and the military structures through the different periods will help to clarify the complexity of the Afghan war.

\section{8 - 1979: Resistance}

This was the period of resistance against the emerging communist regime in Afghanistan. It was initiated in rural areas, by those who feared the new government would bring Soviet forces inside Afghanistan, and make them become communists.

\section{0 - 1989: Jihad}

This was the period of the Mujahedin (Freedom fighters) war against the Soviet occupation. The fighting took the form of frequent attacks on administrative centres and military checkpoints. These were mostly in rural areas, but also took place on the outskirts of towns. Russian soldiers and government forces were fighting against Mujahedin and Muslim militants from other countries. Government soldiers in the regular army numbered about 145,000 at the beginning of the Russian occupation . During this period most of the school buildings were damaged and destroyed. Schools were being used government soldiers as bases, and the resistance considered them hotbeds of foreign ideology. It led to a serious disruption of children's education.

\section{$1989-1992$}

This was a period of war between the Soviet-back regime of President Najibullah and the Mujahedin factions, and was fought both in the rural and urban areas. During this period the forced conscripts with their tribal militias fought against the Mujahedin militants. The fighting in Khost and Jalalabad towns in 1990 were the bloodiest after the killings by the Soviet-Afghan forces in 1980.

\section{$1992-1996$}

A period of fighting between President Burhanuddin Rabani and the various Mujahedin groups divided along ethnic lines. This mostly took place in Kabul and other big cities. About 40,000 people were killed and more than $70 \%$ of the southern part of Kabul city was destroyed. Fighting was between militia factions. The regular government army had entirely disintegrated and finally collapsed. A total of eighteen factions had been involved in Kabul fighting before the arrival of the Taliban.

\section{6 - to the time of this research}

This was the period of fighting between the Taliban and the Northern Alliance. The Taliban captured Herat in 1995, Kabul in 1996, and drove other forces out of the province. The bloodiest fighting had been that of Dasht-e-Farah in 1995, Parwan and Mazar-e-Sharif in May 1997 and August 1998, Bamiyan in September 1998, Parwan in 
May 1999 and in Yakolang in January 2001, Takhar in 2000. Most other provinces allied themselves with the Taliban without fighting.

These complicated wars have spread over two decades. They not only caused the breakdown of the socio-economic fabric of the communities and the country as a whole, but also threatened a disintegration of the entire state. It has devastated the population and given rise to a sense of desperation among the civil community.

\subsection{Report Organisation}

Part 1 presents introductory information which places this research in the context of global concerns about child soldiers. It gives a justification for undertaking it and the child rights agreements that support and inform it. It then covers the background to the war in Afghanistan and its impact on recruitment and child soldiers.

Part 2 presents the research rationale and design of this study. It draws attention to the constraints that have affected the collection, analysis and documentation of the data and explains the problems this has presented in finalising this report.

Part 3 presents the data and its initial analysis. This was collected from the questionnaires that were used to support the individual interviews. This work was undertaken in 2001, by CCA and SC-S. Both a qualitative and quantitative analysis had been undertaken on the questionnaires at that time. However, circumstances then arose which led to the loss of these processes of analysis, and it has not been possible to get in touch with the researchers who undertook it. It is therefore not possible to give a clear explanation of procedures, or a justification of the quantitative analysis. However, this is an important study and the findings need to be made available in order to take the planning for reintegration of war affected adolescents forward in Afghanistan, therefore both the quantitative and qualitative findings have been included in the form they were presented in 2001 , with some editing.

Part 4 explores the qualitative data presented in Part 3 in greater depth and supports it with further comment and analysis. It has drawn out the perspectives of each of the groups of significant adults and focused on three key areas: the reasons why children join armed forces, their experiences while they are in the armed forces, and the psychological impact these experiences had on them.

Part 5 returns to the objectives of this study and discusses how effective this research has been in gathering the necessary data, and what are the key findings for each objective. It makes recommendations on next steps which might be of value to the ongoing work with former child soldiers. 


\section{RESEARCH RATIONALE AND DESIGN}

This research was conducted by CCA and SC-S in the refugee camps in the NWFP and Baluchistan provinces in Pakistan, and by CCA in four regions in Afghanistan, namely Kabul, Kandahar, Bamiyan and Mazar-e-Sharif. The respondents were selected groups of former child soldiers, parents and neighbours, and professionals such as teachers, doctors, former army officers and militia commanders.

There had previously been little information available on the number of children involved in armed conflict in Afghanistan and the impact of armed conflict on them. The objective of this research project was therefore to explore these issues, together with the reason why children were being recruited and what could be done to rehabilitate them.

$\mathrm{CCA}$, as implementing partner, employed one coordinator, three researchers, six surveyors and three monitors. The data in the refugee camps in NWFP and Baluchistan was collected by a group of five surveyors, three were the permanent staff members of $\mathrm{SC}-\mathrm{S}$ and two were from CCA. Surveyors from CCA collected the data inside Afghanistan

\subsection{Objectives}

\section{Overall Objective:}

To explore the effects of armed conflict on the children in Afghanistan.

\section{Specific objectives:}

1. Describe how children living in the refugee villages (camps) and in Afghanistan are psychologically affected by the war.

2. Describe how the Afghan children and the families deal with the experiences from the war, both in the refugee villages and inside Afghanistan.

3. Explore the mechanisms and push factors involved in recruitment of child soldiers and the extent of the problem in Afghanistan.

4. Recommend strategies and programmes to work with children who are psychologically affected by war.

\subsection{Research Methodology}

The research methodology included the following components: 
1. A questionnaire survey to support the life story narratives with former child soldiers. A few case-studies of child soldiers on active duty in Afghanistan were also recorded.

2. A questionnaire survey to guide the interviews with parents and neighbours of former child soldiers, with doctors and teachers, and with relevant political and warring parties and adult combatants (perpetrators / recruiters) in order to support the data collected from the former child soldiers. The respondents were assured of anonymity due to the sensitivity of the topic and the possibility of reprisals.

\subsubsection{Field Research Activities}

The following research tools were used in the field:

\section{Planning and Pre-testing}

The questionnaires were prepared for each target group being interviewed. They were then pre-tested in refugee villages in Peshawar, Pakistan.

\section{Interviews with former child soldiers}

The researchers used prepared questionnaire forms to guide and support the life-story narratives given by former child soldiers. These respondents were defined as having taken up arms before the age of 18 years. They had either fled Afghanistan and were now living in the NWFP and Baluchistan as refugees, or were living in one of the four selected regions in Afghanistan. The questionnaires and narratives were designed to collect information about their experiences of armed conflict, their own direct experience of combat and trauma, and their life since being a child soldier.

\section{Interviews with parents}

The researchers interviewed parents about their children's experiences, and how the family as a unit had coped with the impact of armed conflict, and as refugees in Pakistan or within their communities in Afghanistan.

\section{Interviews with related parties}

Interviews were held with former government army officers, Muhajedin commanders, schoolteachers or directors, doctors and psychiatrists, and with neighbouring families, about their experiences with child soldiers.

\section{Addressing the principles of gender, culture-sensitivity and child-focus}

This research has been guided by the principles of gender and culture-sensitivity and is child-focused. Interviews were conducted with awareness of the norms and values of the Afghan people. For example questions were not asked in a direct question and answer format, but an anthropological approach was used, directed largely by the nuances of the interaction between the researcher and the respondent. Care was taken to guarantee the analysis and interpretation of results was faithful to the respondents' perception of their reality. 


\subsubsection{Time and duration of the Study}

The study was planned to cover eight months, from November 2000 to July 2001.

o Planning and designing the research: This took one week. The questionnaires were prepared for each of the target groups.

- Training: The training was conducted in two phases and aimed to equip the research team with the knowledge and skills to analyse their research needs, and then plan and conduct their research studies.

- Pre-testing: was conducted in two phases.

- Phase one: November $25^{\text {th }}-$ December $6^{\text {th }} 2000$, a pilot exercise with one week of class training followed by 10 days pre-testing in Khan Colony and Board/Hayatabad Area of Peshawar, by a team of four researchers and a monitor from CCA. A total of 212 people were interviewed. The objective of this exercise was to familiarise the researchers with the questionnaires and make necessary amendments

- Phase two: The revised questionnaires were tested more comprehensively both inside Afghanistan and in seven refugee villages in Peshawar. Training was then conducted from January $1^{\text {st }}-20^{\text {th }} 2001$. It included CRC orientation, training needs assessment, design of training modules, actual implementation and documentation, interviewing children, the ethics of doing research with lon children, the effects of armed conflict on children, basic counselling and debriefing.

\subsubsection{Data Collection}

The data was collected over three months. Individual meetings took place with former child soldier, and with parents and the other significant adults. Researchers were careful not to meet with parents and key-informants simultaneously or in front of the former child soldier. This was to maintain confidentiality and to be able to verify information independently. The material collected from these significant adults was for confirming, reinforcing and supporting the data provided by the former child soldiers.

\subsubsection{Data Analysis}

The data was analysed by CCA. This took place over a month and involved summarising and analysing the questionnaire data and supportive interview material. Qualitative and quantitative data was extracted manually and analysed, and has been presented in Part Three of the report. 


\subsection{Preparation of the Report}

The draft final report was written in July and August 2001 and presented to different stakeholders for their comments. It was based on the findings of the research and was illustrated with graphs, tables and photographs.

The writing of this original report had to be handed over to another consultant not directly involved with the research, and concern was later expressed about the fullness of its findings. A further draft was therefore prepared by one of the researchers from CCA. However this had not been completed and SC-S then requested that a further attempt be made to finalise its content. This is therefore the third attempt at a draft of this report.

\subsection{Constraints}

Implementation of the Project: Certain aspects of the original design were not implemented. This has had implications on the depth of its analysis and the quality of its data collection. The following were planned but not implemented.

- A Child Rights Programmer was to have been interviewed for information on programs and services for children in situations of armed conflict and how these can reinforce children's coping capacity.

- An extensive review of related literature from other countries had been planned to support the study, as there is little research so far on Afghan children.

- Monitoring of the surveyors had been scheduled into the Field Research Activities but had not taken place in the refugee camps.

Early departure of the research team leader: Professor Hassanyar, who initiated and coordinated the research, migrated to the US while the survey was in its final stages. Data analysis was then undertaken by other CCA staff. An outside consultant, was hired to write the final report. The consultant had no prior experience in this area nor was he involved at any stage of the research. It was thought by other stakeholders that this had affected the quality of the initial report.

Limitations of Project Design: Time had not been planned for regular meetings of the surveyors while the data was being collected, this meant that they were unable to share experiences or raise problems. Concern was expressed by some of the surveyors that this affected the quality and consistency of the data.

\section{Security issues:}

The on-going war and insiability in Afghanistan created recurring security problems for the surveyors both in the refugee camps and inside Afghanistan. Also the sensitivity surrounding child soldiers, created some security concerns. The infrastructure in the country, with bad roads and non-existing communications in the field, made travel hazardous, and special arrangements would have to be made before visiting any area. Surveyors working in Pakistan met with similar problems, as camps were mainly in tribal areas where communications and security were also problematic. 


\section{PRESENTATION AND DISCUSSION OF FINDINGS}

The material in this section was scored and analysed by CCA in 2001, and presented in the original report together with the tables and graphs. It has not been possible to verify how their categories were selected, and at times it is not clear how the figures in the text relate to what is recorded on the tables and graphs. As the CCA staff are no longer available it has not been possible to resolve these issues, but rather than lose any of the potential of this initial analysis it has been presented here with some editing

This original report presents the data collected from child soldiers and other target groups. It covers the age at which child soldiers were recruited, the numbers which had been involved during different period of the war, the push factors making these children join armed groups, the experiences they have had of being a child soldier, the psychological impact of fighting on them and their resulting addiction to drugs. There is also data on the educational and economic situation among the former child soldiers in refugee camps, but not for Afghanistan. It then presents the views of the significant adults surrounding these former child soldiers, their families and neighbours, army officers and militia commanders, doctors and teachers.

The numbers in each target group interviewed

Table $1:$ Numbers in target groups interviewed

\begin{tabular}{|l|r|r|r|r|r|r|r|r|r|r|}
\hline Area & $\begin{array}{l}\text { No. of } \\
\text { villages }\end{array}$ & Children & Parents & $\begin{array}{l}\text { Army } \\
\text { officers }\end{array}$ & $\begin{array}{l}\text { Militia } \\
\text { comm- } \\
\text { anders }\end{array}$ & $\begin{array}{l}\text { Neigh- } \\
\text { bours }\end{array}$ & Teachers & Doctors & $\begin{array}{l}\text { Profess- } \\
\text { ionals }\end{array}$ & Subtotal \\
\hline NWFP & & & & & & & & & & \\
\hline Quetta & 16 & 459 & 279 & 89 & 190 & 47 & 70 & 38 & 0 & 1372 \\
\hline Afghanistan & 153 & 681 & 323 & 10 & 31 & 23 & 9 & 4 & 0 & 220 \\
\hline TOTAL & 223 & 1385 & 700 & 150 & 284 & 211 & 168 & 96 & 22 & 3016 \\
\hline$\%$ & & $46 \%$ & $23 \%$ & $5 \%$ & $9 \%$ & $7 \%$ & $6 \%$ & $3 \%$ & $1 \%$ & $100 \%$ \\
\hline
\end{tabular}

Altogether 3,016 people were interviewed in 223 locations, both in refugee villages in Pakistan and inside Afghanistan. 1,385 (46\%) of these were former child soldiers. 700 $(23 \%)$ were the parents of child soldiers. $124(5 \%)$ were former militia commanders and another $150(5 \%)$ were former army officers. Neighbours, teachers, doctors, and professionals and volunteers working in the community, made up the remaining 497 $(16 \%)$ 


\subsection{Data from former Child Soldiers}

\subsubsection{Age groups of the child soldier interviewed}

Table 2: Age group of the child soldiers interviewed

\begin{tabular}{|l|r|r|r|r|}
\hline \multirow{2}{*}{ Place } & \multicolumn{4}{|c|}{ Age Range } \\
\hline & under $12 \mathrm{yr}$ & $12 \mathrm{yr}-15 \mathrm{yr}$ & $16 \mathrm{yr}-18 \mathrm{yr}$ & Total \\
\hline North NWFP & $3 \%$ & $52 \%$ & $45 \%$ & $100 \%$ \\
\hline Peshawar & $0 \%$ & $38 \%$ & $62 \%$ & $100 \%$ \\
\hline South NWFP & $0 \%$ & $52 \%$ & $48 \%$ & $100 \%$ \\
\hline Quetta & $4 \%$ & $31 \%$ & $64 \%$ & $100 \%$ \\
\hline Kandahar & $3 \%$ & $57 \%$ & $40 \%$ & $100 \%$ \\
\hline Kabul & $4 \%$ & $67 \%$ & $29 \%$ & $100 \%$ \\
\hline Bamiyan & $4 \%$ & $49 \%$ & $47 \%$ & $100 \%$ \\
\hline Mazar & $6 \%$ & $47 \%$ & $47 \%$ & $100 \%$ \\
\hline \multicolumn{1}{|r|}{ Subtotal } & $3 \%$ & $51 \%$ & $45 \%$ & $100 \%$ \\
\hline
\end{tabular}

\section{Age group of child soldiers interviewed}

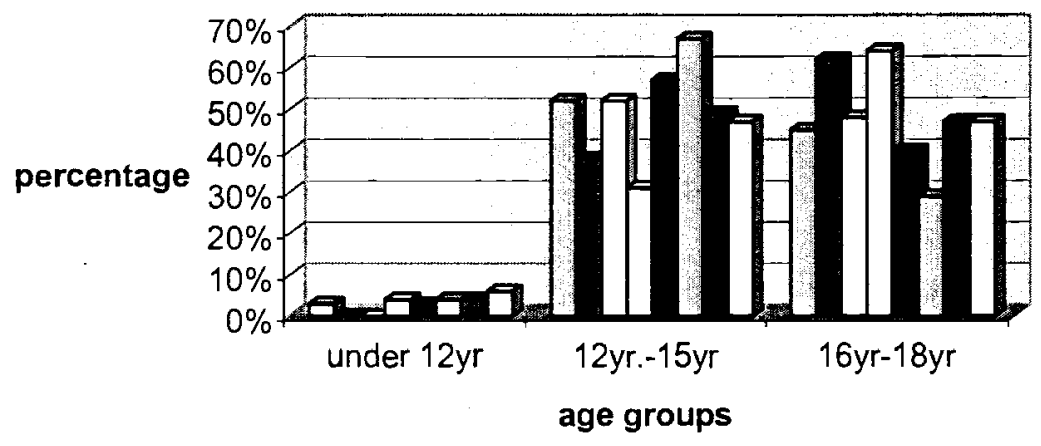

$\square$ North NWFP

- Peshawar

$\square$ South NWFP

$\square$ Quetta

Kandahar

-Kabul

- Bamiyan

口Mazar

Most of the former child soldiers (51\%) had been aged between 12 and 15 years when they were recruited, $45 \%$ had been aged between $16-18$ years. $3 \%$ of the child soldiers interviewed took up arms before they were 12 years old. Two of them had been only 8 years old. 


\subsubsection{Numbers of child soldiers at different periods of the war}

\subsubsection{In refugee camps}

Table 3: Periods of the war and percent of former child soldiers participating from refugee camps

\begin{tabular}{|l|r|r|r|r|r|r|r|r|r|r|}
\hline Years & \multicolumn{2}{|c|}{ North NWFP } & \multicolumn{2}{|c|}{ Peshawar } & \multicolumn{2}{|c|}{ South NWFP } & \multicolumn{2}{|c|}{ Quetta } & \multicolumn{2}{|c|}{ Total } \\
\hline & No. & \multicolumn{1}{c|}{$\%$} & \multicolumn{1}{|c|}{ No. } & \multicolumn{1}{c|}{$\%$} & No. & \multicolumn{1}{c|}{$\%$} & No. & \multicolumn{1}{c|}{$\%$} & \multicolumn{1}{c|}{ No } & $\%$ \\
\hline $1979-89$ & 145 & $31 \%$ & 27 & $27 \%$ & 31 & $32 \%$ & 11 & $24 \%$ & 214 & $30 \%$ \\
\hline $1989-92$ & 91 & $20 \%$ & 23 & $23 \%$ & 21 & $22 \%$ & 8 & $18 \%$ & 143 & $20 \%$ \\
\hline $1992-96$ & 94 & $20 \%$ & 17 & $17 \%$ & 15 & $15 \%$ & 11 & $24 \%$ & 137 & $19 \%$ \\
\hline $1996-01$ & 132 & $29 \%$ & 33 & $33 \%$ & 30 & $31 \%$ & 15 & $33 \%$ & 210 & $30 \%$ \\
\hline Total & 462 & $100 \%$ & 100 & $100 \%$ & 97 & $100 \%$ & 45 & $100 \%$ & 704 & $100 \%$ \\
\hline
\end{tabular}

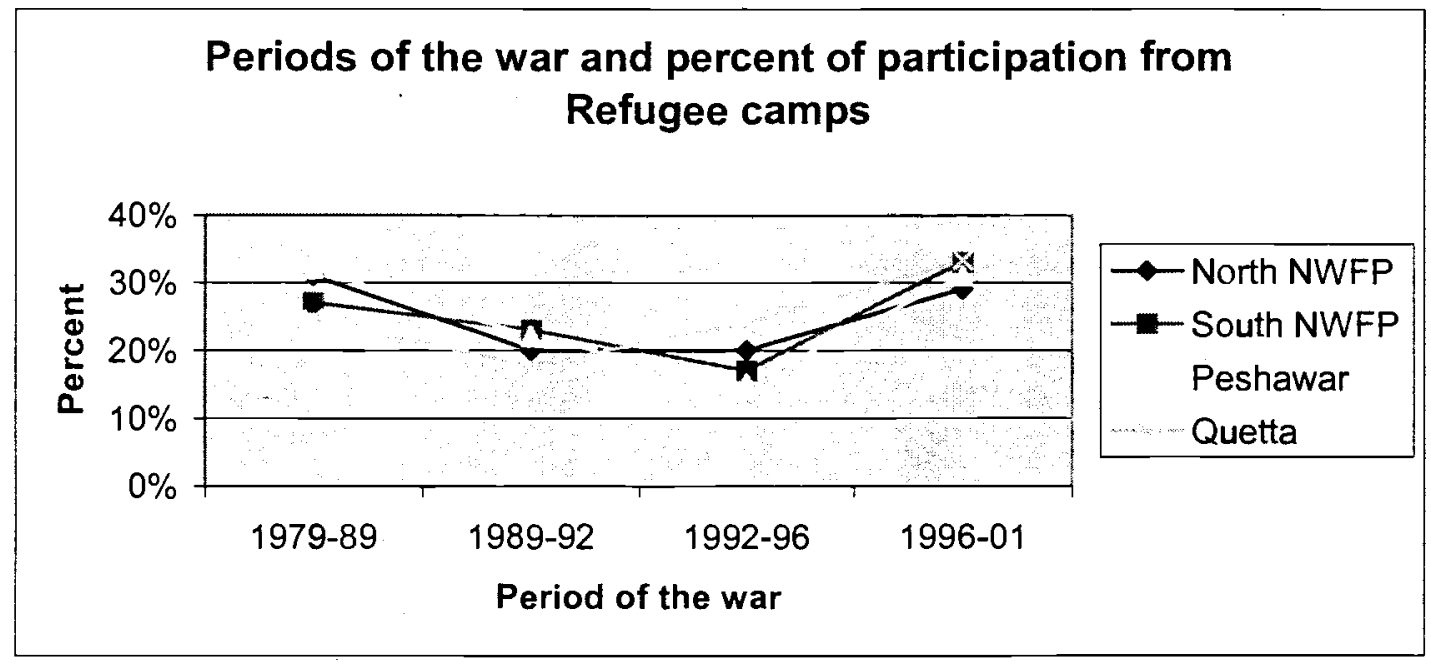

Most of the former child soldiers (30\%) were recruited from the refugee camps during two periods. The first was during the Russian invasion from $1979-89$. This was the Jihad when Afghans volunteered in huge numbers to fight for their religion, and their freedom. The other was after the Taliban came to power in 1996, and reflects the support they had from the refugee camps.

\subsubsection{Inside Afghanistan}

Table 4: Periods of the war and percent of former child soldiers participating from Afghanistan

\begin{tabular}{|l|r|r|r|r|r|r|r|r|r|r|}
\hline Years & \multicolumn{2}{|c|}{ Kandahar } & \multicolumn{2}{|c|}{ Kabul } & \multicolumn{2}{c|}{ Bamiyan } & \multicolumn{2}{c|}{ Mazar } & \multicolumn{2}{|c|}{ Total } \\
\hline & No. & \multicolumn{1}{c|}{$\%$} & \multicolumn{1}{|c|}{ No. } & \multicolumn{1}{c|}{$\%$} & No. & \multicolumn{1}{c|}{$\%$} & No. & \multicolumn{1}{c|}{$\%$} & \multicolumn{1}{c|}{ No } & \multicolumn{1}{c|}{$\%$} \\
\hline $1979-89$ & 44 & $49 \%$ & 74 & $40 \%$ & 78 & $38 \%$ & 92 & $45 \%$ & 288 & $42 \%$ \\
\hline $1989-92$ & 12 & $13 \%$ & 43 & $23 \%$ & 35 & $17 \%$ & 56 & $28 \%$ & 146 & $21 \%$ \\
\hline $1992-96$ & 16 & $18 \%$ & 30 & $16 \%$ & 46 & $23 \%$ & 34 & $17 \%$ & 126 & $19 \%$ \\
\hline $1996-01$ & 18 & $20 \%$ & 37 & $20 \%$ & 45 & $22 \%$ & 21 & $10 \%$ & 121 & $18 \%$ \\
\hline Total & 90 & $100 \%$ & 184 & $100 \%$ & 204 & $100 \%$ & 203 & $100 \%$ & 681 & $100 \%$ \\
\hline
\end{tabular}




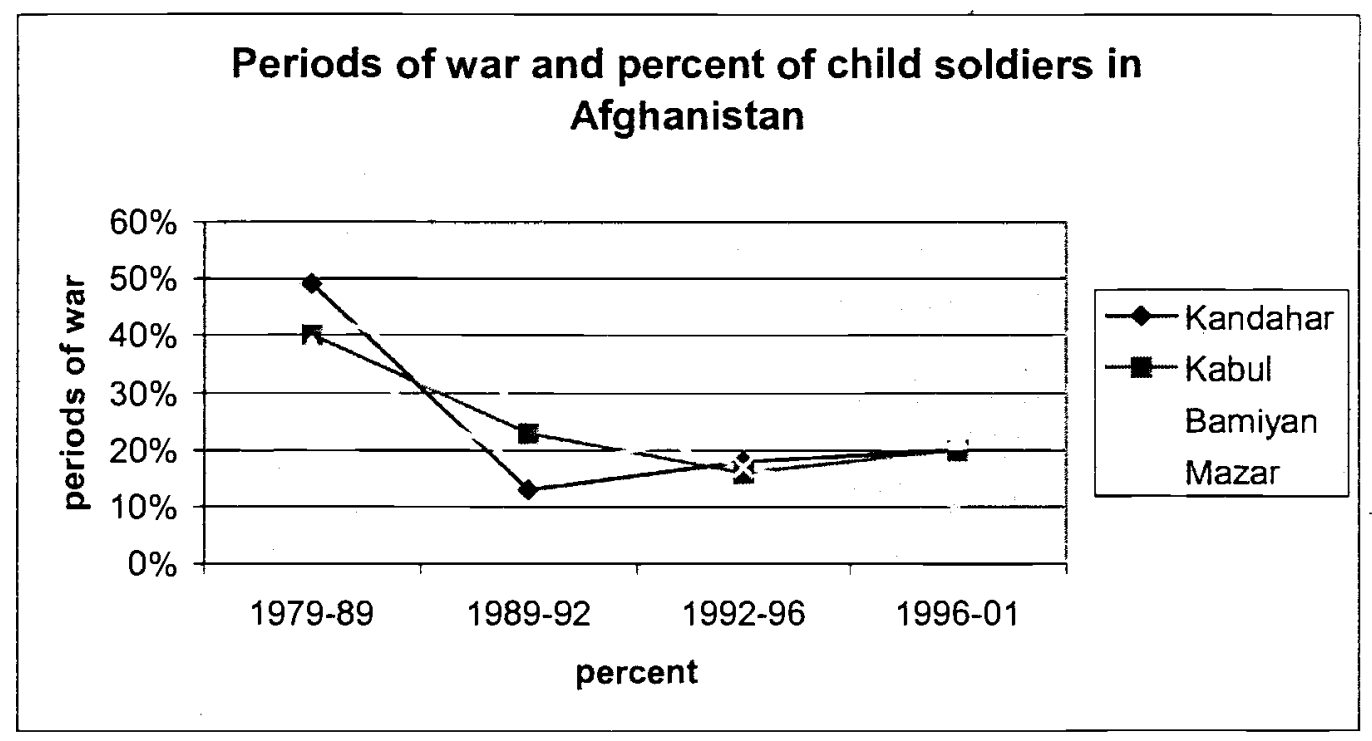

$42 \%$ of child soldiers were recruited between 1979-1989, in response to the invasion by Russia. When the Russians were repulsed the numbers halved to $21 \%$ and then continued to fall slowly throughout the period of civil war when communities were divided over allegiance to warlords. Unlike the refugee camps, the numbers did not rise when the Taliban came to power, this may be linked to the strict laws adhered to by the Talibans concerning children: Only those who had grown a beard were old enough to fight.

\subsubsection{The reason why children became soldiers}

\subsubsection{In refugee villages}

Table 5: Reasons given why children became soldiers in refugee caps

\begin{tabular}{|l|r|r|r|r|r|r|}
\hline & \multicolumn{2}{|c|}{ NWFP } & \multicolumn{2}{|c|}{ Quetta } & \multicolumn{2}{c|}{ Total } \\
\hline At their own wish & 9 & $1 \%$ & 0 & $0 \%$ & 9 & $1 \%$ \\
\hline By force & 44 & $7 \%$ & 1 & $2 \%$ & 45 & $6 \%$ \\
\hline Economical & 142 & $22 \%$ & 28 & $62 \%$ & 170 & $24 \%$ \\
\hline Ethnicity & 29 & $4 \%$ & 0 & $0 \%$ & 29 & $4 \%$ \\
\hline Family encouragement & 64 & $10 \%$ & 2 & $4 \%$ & 66 & $9 \%$ \\
\hline Ideological & 340 & $52 \%$ & 13 & $29 \%$ & 354 & $52 \%$ \\
\hline Jobless & 0 & $0 \%$ & 0 & $0 \%$ & 0 & $0 \%$ \\
\hline Lack of awareness & 1 & $0 \%$ & 0 & $0 \%$ & 1 & $0 \%$ \\
\hline Political & 27 & $4 \%$ & 1 & $2 \%$ & 28 & $4 \%$ \\
\hline Revenge & 2 & $0 \%$ & 0 & $0 \%$ & 2 & $0 \%$ \\
\hline Total & 658 & $100 \%$ & 45 & $100 \%$ & 703 & $100 \%$ \\
\hline
\end{tabular}




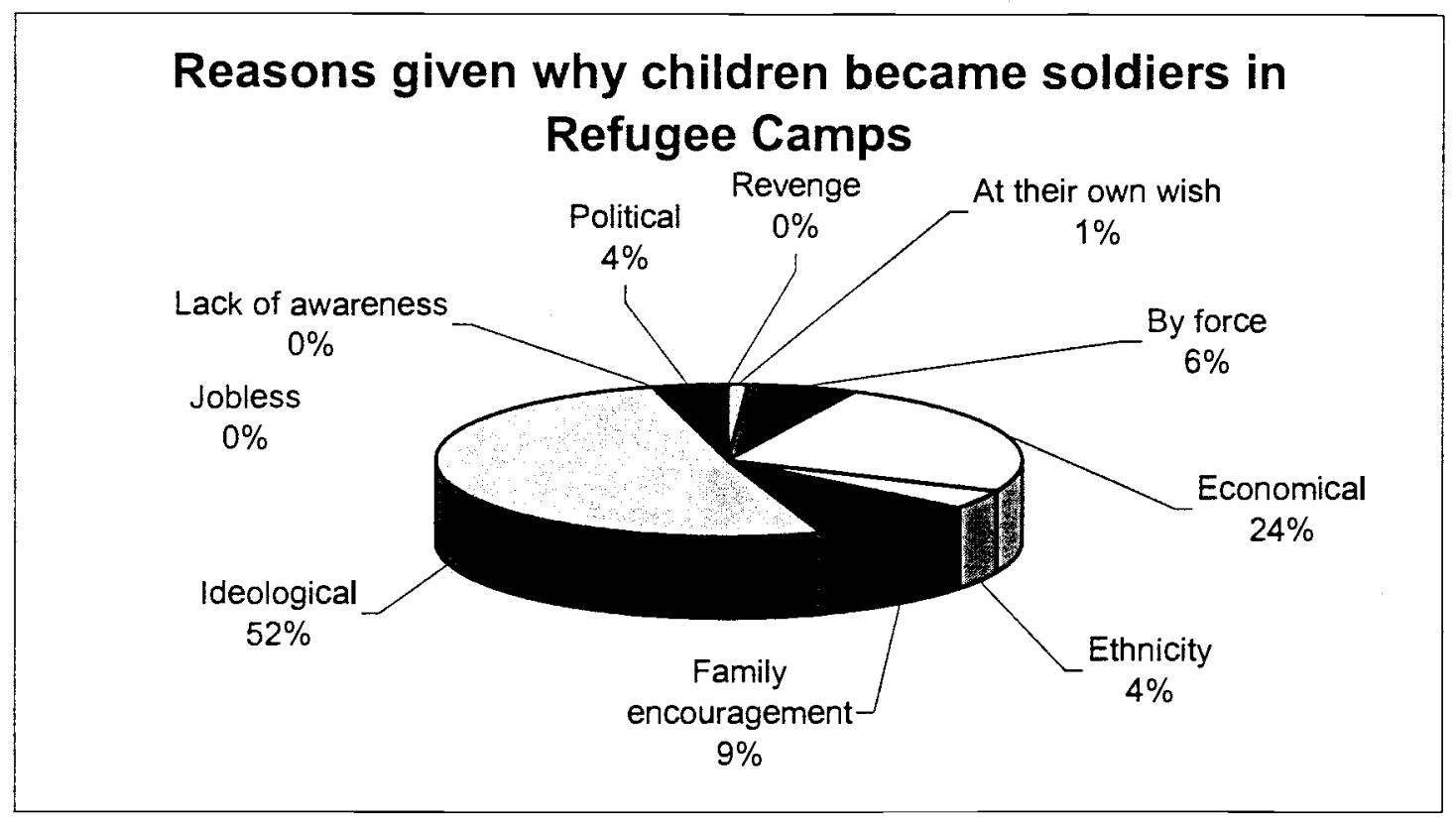

704 former child soldiers were interviewed in the refugee villages in Pakistan. Of these $354(52 \%)$ said it was to defend their country against invaders and for religious beliefs. $170(24 \%)$ said it was due to poverty and their economic problems. 66 (9\%) said they had been encouraged by their family and feared being criticised by others for not fighting. $45(6 \%)$ said they had been forced to take up arms and $28(4 \%)$ said it was for ethnic reasons, as there had been tribal competition for territorial control. Arms had been freely available and the gun was not only for defence but also a symbol of their cultural pride and power. $9(1 \%)$ said they had gone of their own free will and out of curiosity.

In comparing the data of NWFP and Baluchistan refugee camps, the ideological factor was strongest in NWFP (52\%) where there have been more Afghan refugees. The economic factor was strongest in Baluchistan refugee camps (62\%). Baluchistan had a big Shiite community of Hazaras, this is a minority group where there is much poverty.

\section{Educational Status of former child soldiers in the refugee camps}

Table 6: Educational status of the former child soldiers interviewed in refugee villages

\begin{tabular}{|l|r|r|r|r|r|r|}
\hline Level of education & \multicolumn{2}{|c|}{ NWFP } & \multicolumn{2}{c|}{ Quetta } & \multicolumn{2}{|c|}{ Total } \\
\hline Illiterate & 318 & $48 \%$ & 20 & $44 \%$ & 338 & $48 \%$ \\
\hline madrassa & 17 & $3 \%$ & 2 & $4 \%$ & 19 & $3 \%$ \\
\hline Primary school & 114 & $17 \%$ & 10 & $22 \%$ & 124 & $18 \%$ \\
\hline Middle school & 84 & $13 \%$ & 9 & $20 \%$ & 93 & $13 \%$ \\
\hline High school & 82 & $12 \%$ & 4 & $9 \%$ & 86 & $12 \%$ \\
\hline University & 44 & $7 \%$ & 0 & $0 \%$ & 44 & $6 \%$ \\
\hline
\end{tabular}


$338(48 \%)$ of the former child soldiers from the refugee camps had no education at all. Though the others had had some form of primary education, either in schools or religious madrassa, the majority had no education available to them after $6^{\text {th }}$ grade.

In comparing data from NWFP and Baluchistan the greatest difference is in the number with a university education, $44(7 \%)$ of those in NWFP had received this, while none had in Baluchistan. NWFP had many advantages over Baluchistan. It was much more accessible. It had many more refugees and facilities for them. There was a much stronger international presence and numerous NGO initiatives. It is a centre for political activities and has the headquarters of different Afghan political parties. The level of motivation for refugees was much higher in NWFP than in Baluchistan. This may be because of the concentration of Afghan political parties and the free flow of money to them from different western and Arab countries.

\section{The Economic situation in refugee camps}

Table 7: Data from refugees on economic status of former child soldiers

\begin{tabular}{|c|c|c|c|c|c|c|c|c|c|c|}
\hline Source of income & North & NWFP & Sout & NWFP & Pest & awar & & setta & Tot & \\
\hline Not paid, fed only & 240 & $52 \%$ & 52 & $54 \%$ & 40 & $40 \%$ & 26 & $58 \%$ & 358 & $51 \%$ \\
\hline Daily wage & 0 & $0 \%$ & 0 & $0 \%$ & 0 & $0 \%$ & 1 & $2 \%$ & 1 & $0 \%$ \\
\hline Paid monthly + food & 58 & $13 \%$ & 12 & $12 \%$ & 39 & $39 \%$ & 10 & $22 \%$ & 119 & $17 \%$ \\
\hline Substance allowances & 119 & $26 \%$ & 17 & $18 \%$ & 14 & $14 \%$ & 7 & $16 \%$ & 157 & $22 \%$ \\
\hline Family support & 28 & $6 \%$ & 13 & $13 \%$ & of & $0 \%$ & 0 & $0 \%$ & 41 & $6 \%$ \\
\hline Sold looted items & 16 & $3 \%$ & 3 & $3 \%$ & 7 & $7 \%$ & 1 & $2 \%$ & 27 & $4 \%$ \\
\hline No information & 1 & $0 \%$ & 0 & $0 \%$ & 0 & $0 \%$ & 0 & $0 \%$ & 1 & $0 \%$ \\
\hline Total & 462 & $100 \%$ & 97 & $100 \%$ & 100 & $100 \%$ & 45 & $100 \%$ & 704 & $100 \%$ \\
\hline
\end{tabular}

$358(51 \%)$ former child soldiers said they were not paid and only received food. Only one said he received daily wages. $157(22 \%)$ were paid substance allowance. $119(17 \%)$ were given food and also a monthly salary. This was most common among the governmenthired child soldiers who were mostly from Peshawar. $41(6 \%)$ said they had used their family resources to pay for their time with the armed groups. This would only have happened in the early years of the Jihad. Respondents who used family assets were mostly from the southern camps in the NWFP. $27(4 \%)$ said they looted and sold the items to proxide cash for their expenses. Ionting was common among the tribal militia and semi-government soldiers. It was also taking plase among some Mujahedin groups in the late $1980 \mathrm{~s}$. It was religious practice that anything captured from the enemy, referred to as "Maal-e-Ghanimat", should be equally distributed among the warriors. Soldiers serving at checkpoints along the main roads would also supplement their income by taking tributes from drivers and passengers. 


\subsubsection{Inside Afghanistan}

Table 8: Reasons given why children became soldiers in Afghanistan

\begin{tabular}{|l|r|r|r|r|r|r|r|r|r|r|}
\multicolumn{2}{c}{ Kandahar Kabul/Jallal } & \multicolumn{2}{c}{ Bamiyan } & \multicolumn{2}{c}{ Mazar } \\
\hline Economical & 7 & $8 \%$ & 25 & $14 \%$ & 37 & $18 \%$ & 46 & $23 \%$ & 115 & $17 \%$ \\
\hline Family encouragement & 4 & $4 \%$ & 21 & $11 \%$ & 14 & $7 \%$ & 19 & $9 \%$ & 58 & $9 \%$ \\
\hline Family problems & 2 & $2 \%$ & 0 & $0 \%$ & 6 & $3 \%$ & 9 & $4 \%$ & 17 & $2 \%$ \\
\hline Force & 25 & $28 \%$ & 17 & $9 \%$ & 65 & $32 \%$ & 31 & $15 \%$ & 138 & $21 \%$ \\
\hline Moral & 2 & $2 \%$ & 15 & $8 \%$ & 0 & $0 \%$ & 0 & $0 \%$ & 17 & $2 \%$ \\
\hline Political & 21 & $23 \%$ & 32 & $17 \%$ & 30 & $15 \%$ & 22 & $11 \%$ & 105 & $15 \%$ \\
\hline Regional competition & 1 & $1 \%$ & 13 & $7 \%$ & 9 & $4 \%$ & 8 & $4 \%$ & 31 & $5 \%$ \\
\hline Relationship & 4 & $4 \%$ & 15 & $8 \%$ & 25 & $12 \%$ & 15 & $7 \%$ & 59 & $9 \%$ \\
\hline Religion & 9 & $10 \%$ & 13 & $7 \%$ & 0 & $0 \%$ & 14 & $7 \%$ & 36 & $5 \%$ \\
\hline Revenge & 4 & $4 \%$ & 9 & $5 \%$ & 5 & $2 \%$ & 7 & $3 \%$ & 25 & $4 \%$ \\
\hline School pressure & 5 & $6 \%$ & 0 & $0 \%$ & 0 & $0 \%$ & 5 & $2 \%$ & 10 & $1 \%$ \\
\hline Volunteer & 6 & $7 \%$ & 24 & $13 \%$ & 13 & $6 \%$ & 27 & $13 \%$ & 70 & $10 \%$ \\
\hline Total & $\mathbf{9 0}$ & $100 \%$ & 184 & $100 \%$ & 204 & $100 \%$ & 203 & $100 \%$ & 681 & $100 \%$ \\
\hline
\end{tabular}

\section{Reasons given why children became soldiers in}

\section{Afghanistan}

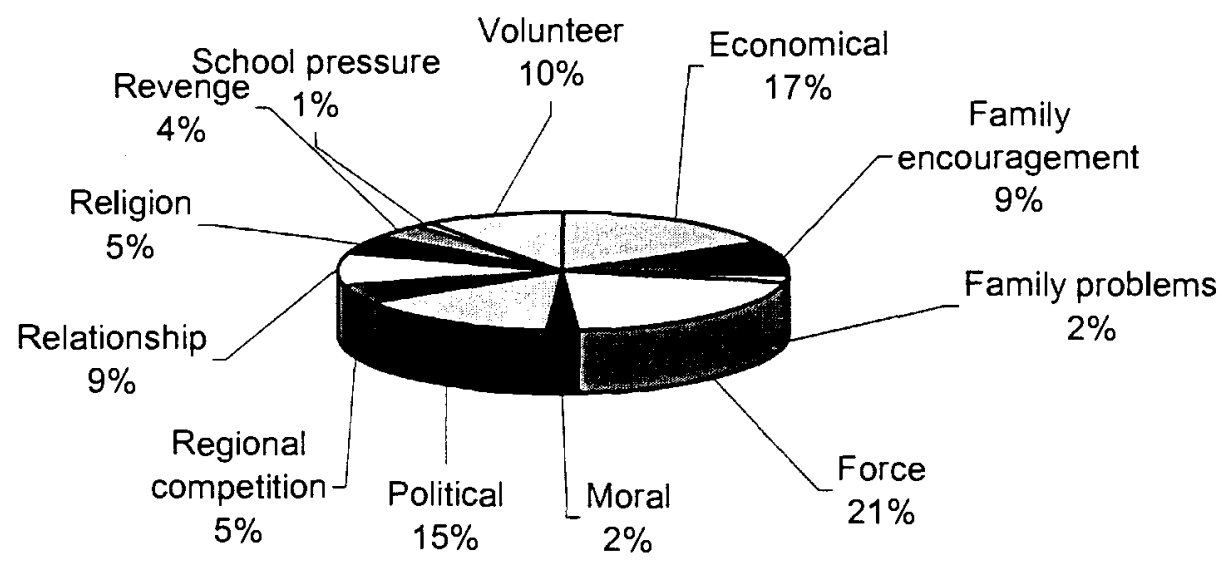

681 former child soldiers were interviewed in Afghanistan.138 (21\%) said they were forcefully recruited, making this the strongest factor. Each side was needing to replenish its fighting strength. Economical reasons were given by 115 (17\%), "making it the second most influential factor. $105(15 \%)$ child soldiers had joined for political reasons. 70 (10\%) had volunteered and $59(9 \%)$ had a relative already in the army. Another $58(9 \%)$ became soldiers because of family persuasion. Only 5\% were recruited on religious grounds in comparison to the $50 \%$ in the refugee camps. 
Comparing the different zones, Bamiyan and Kandahar had the most child soldiers taken by force. Khandahar and Kabul/Jalalabad had the most joining because of political affiliation. In Bamiyan and Kabul/Jalalabad the economic factor was strongest.

\subsubsection{Psychological Impact of fighting on former child soldiers}

\subsubsection{In refugee camps}

Table 9: The Psychological Problems of Former Child Soldiers in Refugee Camps

\begin{tabular}{|l|r|r|r|r|r|r|r|r|r|r|}
\hline & \multicolumn{2}{|c|}{ North NWFP South NWFP Peshawar } & \multicolumn{2}{|c|}{ Quetta } & \multicolumn{2}{|c|}{ Total } \\
\hline No specific change in behaviour & 255 & $55 \%$ & 64 & $66 \%$ & 62 & $62 \%$ & 29 & $64 \%$ & 410 & $58 \%$ \\
\hline Anxiety & 12 & $3 \%$ & 2 & $2 \%$ & 0 & $0 \%$ & 1 & $2 \%$ & 15 & $2 \%$ \\
\hline Depression & 53 & $11 \%$ & 19 & $20 \%$ & 25 & $25 \%$ & 0 & $0 \%$ & 97 & $14 \%$ \\
\hline Different complexes & 8 & $2 \%$ & 0 & $0 \%$ & 0 & $0 \%$ & 0 & $0 \%$ & 8 & $1 \%$ \\
\hline Disorders & 15 & $3 \%$ & 0 & $0 \%$ & 0 & $0 \%$ & 0 & $0 \%$ & 15 & $2 \%$ \\
\hline Fear & 33 & $7 \%$ & 5 & $5 \%$ & 0 & $0 \%$ & 0 & $0 \%$ & 38 & $5 \%$ \\
\hline Nightmares & 26 & $6 \%$ & 6 & $6 \%$ & 0 & $0 \%$ & 2 & $4 \%$ & 34 & $5 \%$ \\
\hline Hopelessness & 4 & $1 \%$ & 0 & $0 \%$ & 2 & $2 \%$ & 1 & $2 \%$ & 7 & $1 \%$ \\
\hline Interested in going to the armed bases & 15 & $3 \%$ & 0 & $0 \%$ & 0 & $0 \%$ & 0 & $0 \%$ & 15 & $2 \%$ \\
\hline Mentally unbalanced & 5 & $1 \%$ & 1 & $1 \%$ & 1 & $1 \%$ & 0 & $0 \%$ & 7 & $1 \%$ \\
\hline Nervousness & 23 & $5 \%$ & 0 & $0 \%$ & 9 & $9 \%$ & 2 & $4 \%$ & 34 & $5 \%$ \\
\hline Sleeplessness & 13 & $3 \%$ & 0 & $0 \%$ & 1 & $1 \%$ & 9 & $20 \%$ & 23 & $3 \%$ \\
\hline Violence & 0 & $0 \%$ & 0 & $0 \%$ & 0 & $0 \%$ & 1 & $2 \%$ & 1 & $0 \%$ \\
\hline Total & 462 & $100 \%$ & 97 & $100 \%$ & 100 & $100 \%$ & 45 & $100 \%$ & 704 & $100 \%$ \\
\hline
\end{tabular}

Interviews in 223 villages revealed that $80 \%$ of the former child soldiers had witnessed the killing of their comrades or opposition on the front line. Four hundred of the former child soldiers said that they had participated in active fighting and had killed hundreds of the enemy on the battlefield.

$42 \%$ of them suffer from long-term behavioural problems as a result of their experiences in the war. Some $25 \%$ of them were unable to control frustration or anger. They could not monitor or control their violent behaviour and had no insight into the consequences of their actions. They also showed no concern for other members of their family. $14 \%$ suffered some form of depression, $15 \%$ experienced fear, nervousness and nightmares (5\% each), others suffered from sleeplessness and anxiety and had lost hope. A few had become mentally unbalanced. Only $2 \%$ were interested in taking up arms again. Although $58 \%$ of the former child soldiers report no specific changes in behaviour, observations by the surveyors suggested mental disturbance, and sometimes their answers and responses were irrational. 


\subsubsection{Inside Afghanistan}

Table 10: The Psychological Problems of Former Child Soldiers in Afghanistan

\begin{tabular}{|l|r|r|r|r|r|r|r|r|r|r|}
\hline & \multicolumn{2}{|c|}{ Kandahar } & \multicolumn{2}{|c|}{ Kabul/Jallal } & \multicolumn{2}{|c|}{ Bamiyan } & \multicolumn{2}{|c|}{ Mazar } & \multicolumn{2}{|c|}{ Total } \\
\hline Rudeness & 8 & $9 \%$ & 25 & $14 \%$ & 21 & $10 \%$ & 9 & $4 \%$ & 63 & $9 \%$ \\
\hline Argumentative, stubborn & 5 & $6 \%$ & 13 & $7 \%$ & 14 & $7 \%$ & 6 & $3 \%$ & 38 & $6 \%$ \\
\hline Disorder & 14 & $16 \%$ & 20 & $11 \%$ & 32 & $16 \%$ & 8 & $4 \%$ & 74 & $11 \%$ \\
\hline Disturbing others & 3 & $3 \%$ & 14 & $8 \%$ & 5 & $2 \%$ & 11 & $5 \%$ & 33 & $5 \%$ \\
\hline Fear & 6 & $7 \%$ & 22 & $12 \%$ & 11 & $5 \%$ & 13 & $6 \%$ & 52 & $8 \%$ \\
\hline Anxiety & 7 & $8 \%$ & 23 & $13 \%$ & 40 & $20 \%$ & 34 & $17 \%$ & 104 & $15 \%$ \\
\hline Pessimism & 4 & $4 \%$ & 14 & $8 \%$ & 13 & $6 \%$ & 30 & $15 \%$ & 61 & $9 \%$ \\
\hline Nervousness & 13 & $14 \%$ & 29 & $16 \%$ & 26 & $13 \%$ & 45 & $22 \%$ & 113 & $17 \%$ \\
\hline Carelessness/indifference & 4 & $4 \%$ & 14 & $8 \%$ & 15 & $7 \%$ & 17 & $8 \%$ & 50 & $7 \%$ \\
\hline Talking with himself & 5 & $6 \%$ & 5 & $3 \%$ & 3 & $1 \%$ & 5 & $2 \%$ & 18 & $3 \%$ \\
\hline Sensitiveness/disordered & 20 & $22 \%$ & 5 & $3 \%$ & 22 & $11 \%$ & 23 & $11 \%$ & 70 & $10 \%$ \\
\hline Madness & 1 & $1 \%$ & 0 & $0 \%$ & 2 & $1 \%$ & 2 & $1 \%$ & 5 & $1 \%$ \\
\hline Total & 90 & $100 \%$ & 184 & $100 \%$ & 204 & $100 \%$ & 203 & $100 \%$ & 681 & $100 \%$ \\
\hline
\end{tabular}

Inside Afghanistan the findings show that all the former child soldiers were suffering from some form of psychological disturbance as a result of their experiences. 22\% had some form of sensual disorder, $17 \%$ were experiencing nervousness and $15 \%$ were suffering from anxiety. Rudeness (9\%) and pessimism (9\%) was also prevalent, while other characteristics were indifference and mental instability.

\subsubsection{Addiction to Drugs}

Table 11: Addiction to drugs among former child soldiers

\begin{tabular}{|l|r|r|r|r|r|r|r|r|r|}
\hline & $\begin{array}{l}\text { North } \\
\text { NWFP }\end{array}$ & \multicolumn{1}{l}{$\begin{array}{l}\text { South } \\
\text { NWFP }\end{array}$} & Peshawar & Quetta & Kandahar & Kabul & Bamiyan & \multicolumn{1}{l|}{ Mazar } & \multicolumn{1}{l}{ Total } \\
\hline Not addicted & 230 & 35 & 37 & 22 & 0 & 0 & 0 & 16 & 340 \\
\hline Cigarettes & 102 & 20 & 31 & 16 & 10 & 43 & 81 & 34 & 337 \\
\hline Hashish & 43 & 12 & 10 & 4 & 59 & 84 & 24 & 118 & 354 \\
\hline Naswar & 87 & 30 & 20 & 3 & 3 & 22 & 92 & 0 & 257 \\
\hline Opium & 0 & 0 & 0 & 0 & 13 & 22 & 7 & 2 & 44 \\
\hline Herion & 0 & 0 & 2 & 0 & 1 & 7 & 0 & 8 & 18 \\
\hline Alcohol & 0 & 0 & 0 & 0 & 4 & 6 & 0 & 25 & 35 \\
\hline Total & 462 & 97 & 100 & 45 & 90 & 184 & 204 & 203 & 1385 \\
\hline
\end{tabular}




\subsubsection{In refugee camps}

Table 12: Percentage addiction among former child soldiers in Refugee camps

\begin{tabular}{|l|r|r|r|r|r|}
\hline & $\begin{array}{l}\text { North } \\
\text { NWFP }\end{array}$ & $\begin{array}{l}\text { South } \\
\text { NWFP }\end{array}$ & Peshawar & \multicolumn{1}{l|}{ Quetta } & Total \\
\hline Not addicted & $50 \%$ & $36 \%$ & $37 \%$ & $49 \%$ & $46 \%$ \\
\hline Cigarettes & $22 \%$ & $21 \%$ & $31 \%$ & $36 \%$ & $24 \%$ \\
\hline Hashish & $9 \%$ & $12 \%$ & $10 \%$ & $9 \%$ & $10 \%$ \\
\hline Naswar & $19 \%$ & $31 \%$ & $20 \%$ & $7 \%$ & $20 \%$ \\
\hline Opium & $0 \%$ & $0 \%$ & $0 \%$ & $0 \%$ & $0 \%$ \\
\hline Herion & $0 \%$ & $0 \%$ & $2 \%$ & $0 \%$ & $0 \%$ \\
\hline Alcohol & $0 \%$ & $0 \%$ & $0 \%$ & $0 \%$ & $0 \%$ \\
\hline Total & $100 \%$ & $100 \%$ & $100 \%$ & $100 \%$ & $100 \%$ \\
\hline
\end{tabular}

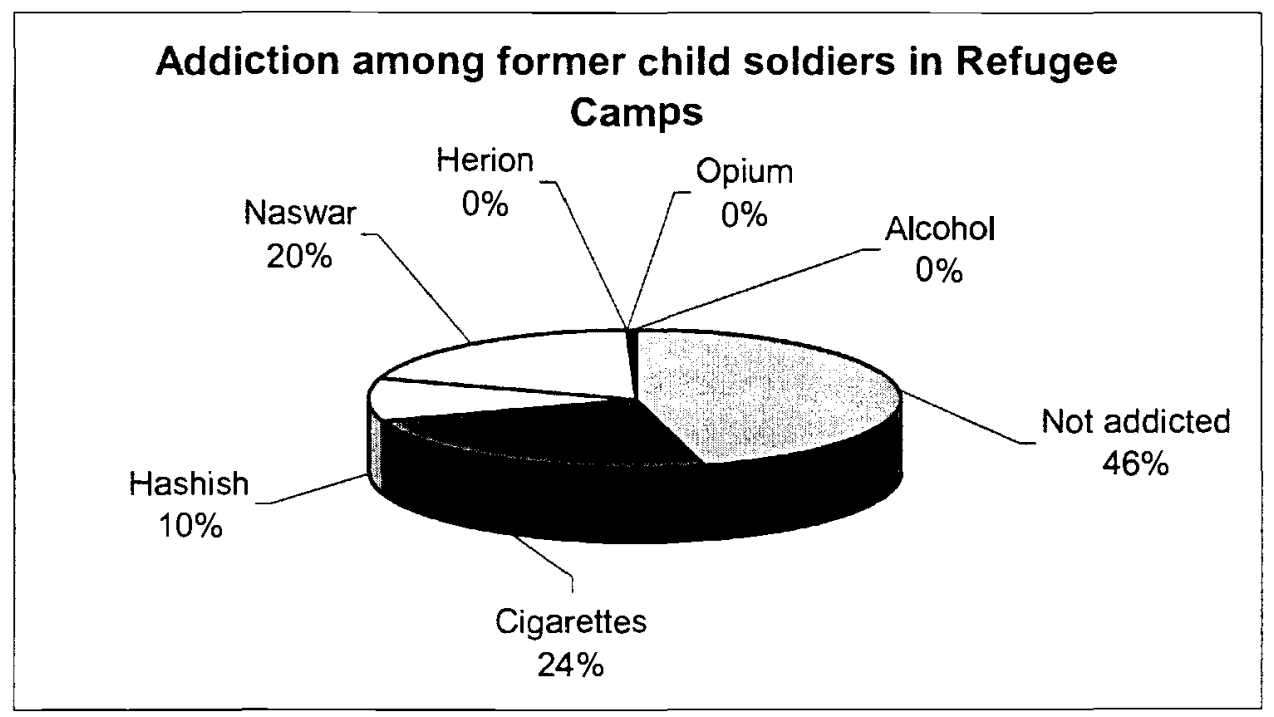

324 (46\%) former child soldiers in refugee camps said they were not addicted to any form of tranquillizer. 169 (24\%) smoked cigarettes, 140 (20\%) took the traditional tobacco paste called naswar. 69 (10\%) said they smoked hashish. Two former child soldiers had been addicted to heroin.

A comparison of the different refugee areas shows that there is less addiction to tranquillizers in the northern camps, with 230 (50\%) former child soldiers with no drug dependency. There was more addiction to cigarettes in refugee camps in the towns of Quetta (36\%) and Peshawar (31\%) than in those in the North NWFP (22\%) and South NWFP $(21 \%)$. The addiction to Hashish is similar in each of the areas with the most in the South NWFP (12\%) and the leost. in Quetta and North NWFP (9\%). Addiction to the tobacco paste 'naswar', which is the most traditional substance varies widely, with most in the South NWFP (31\%) and least in Quetta (7\%) 


\subsubsection{Inside Afghanistan}

Table 13: Addiction among former child soldiers in Afghanistan

\begin{tabular}{|l|r|r|r|r|r|}
\cline { 2 - 6 } \multicolumn{1}{c|}{} & Kandahar & Kabul & Bamiyan & Mazar & Total \\
\hline Not addicted & $0 \%$ & $0 \%$ & $0 \%$ & $8 \%$ & $2 \%$ \\
\hline Cigarettes & $11 \%$ & $23 \%$ & $40 \%$ & $17 \%$ & $25 \%$ \\
\hline Hashish & $66 \%$ & $46 \%$ & $12 \%$ & $58 \%$ & $42 \%$ \\
\hline Naswar & $3 \%$ & $12 \%$ & $45 \%$ & $0 \%$ & $17 \%$ \\
\hline Opium & $14 \%$ & $12 \%$ & $3 \%$ & $1 \%$ & $6 \%$ \\
\hline Herion & $1 \%$ & $4 \%$ & $0 \%$ & $4 \%$ & $2 \%$ \\
\hline Alcohol & $4 \%$ & $3 \%$ & $0 \%$ & $12 \%$ & $5 \%$ \\
\hline Total & $100 \%$ & $100 \%$ & $100 \%$ & $100 \%$ & $100 \%$ \\
\hline
\end{tabular}

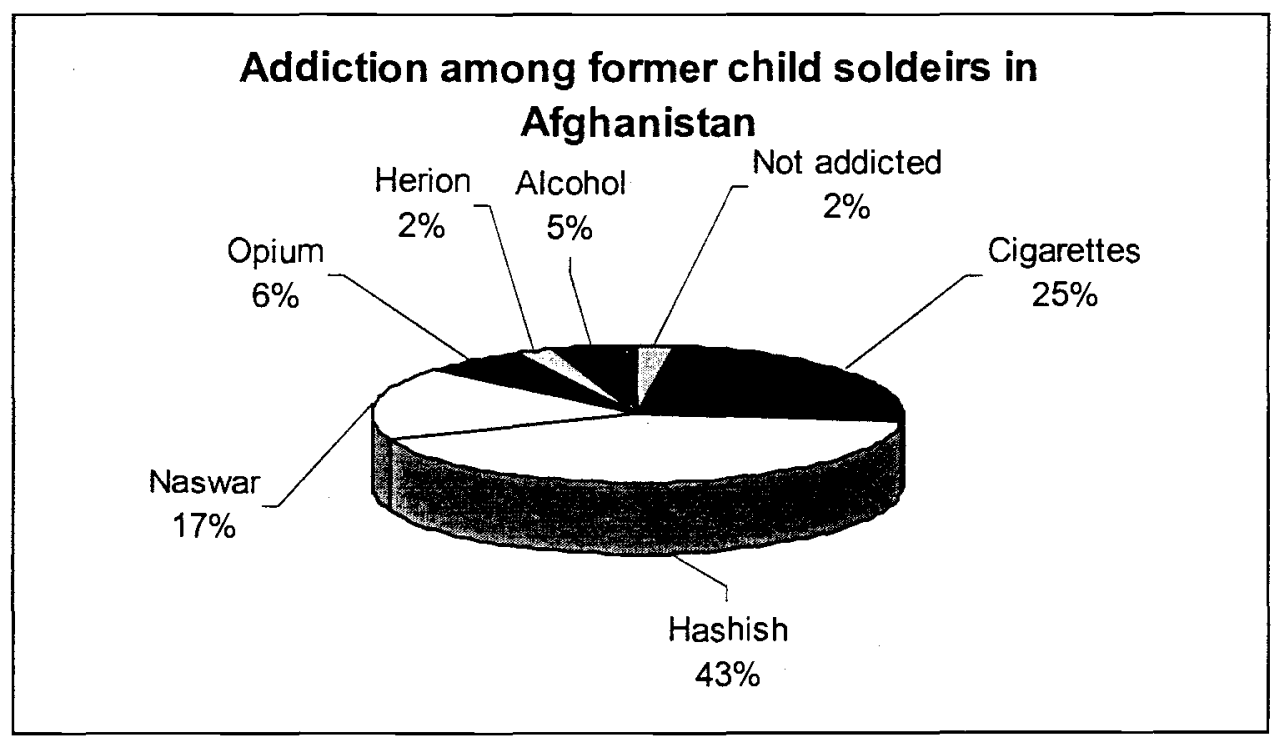

Addiction was much higher among former child soldiers who were recruited inside Afghanistan than among those recruited from the refugee camps. Only $2 \%$ from Afghanistan were not addicted to any tranquillizer compared with the $46 \%$ in the refugee camps. It could be that stronger ideological commitment found among the refugees gave them more resilience. Inside Afghanistan, child soldiers were recruited by the government and tribal militia and were more often taken by force, they were more frustrated and had more need of tranquillisers. Alcohol and other drugs were being provided to the government soldiers and their affiliated militia bonds, both during the communist regime and the civil war.

Hashish was the most common tranquillizer used in three of the four zones in Afghanistan, with Kandahar having the highest percentage (66\%). In Bamiyan, naswar and cigarettes were more common than hashish. Opium was used most in Kandahar and Kabul where it was locally produced. The most heroin was used in Kabul and Mazar, it is produced in factories in the border tribal belt and then exported. 
In Mazar there was more addiction to alcohol than in the other zones, as Russian Vodka was abundant, however almost no one used naswar as it would have been considered old fashioned there. This was the only zone where there were former child soldiers with no addiction to any tranquillizers .

It should be noted that both naswar and cigarettes are so prevalent that they are not considered in the same category as the other drugs and possibly went un-recorded for this reason. This would need further investigation.

\subsection{Data from other target groups}

\subsubsection{Families of former child soldiers}

\section{Refugee villages in NWFP and Baluchistan}

\section{North NWFP:}

176 families were interviewed. $40 \%$ (70) of the families satisfied with having sent their children to Jihad. $31 \%$ (54) of families were not satisfied. They felt that the children had had no opportunity for schooling or acquiring employable skills. Living with armed groups was not a normal lifestyle. The former child soldiers had become aggressive and often treated their families harshly. Most of them have not managed to secure proper jobs and suffered from depression. 20\% (35) said that their children had been taken by force or they had had to pay compensation.

\section{Peshawar:}

3 families were interviewed. All were dissatisfied with their children going to war. They said that, after the children had served with armed groups, they had not behaved normally. These former child soldiers were troubled by their experiences, they talked to themselves and were often pessimistic.

\section{South NWFP:}

100 families were interviewed. Only 27\% (27) were satisfied with their children having spent time on the Jihad. They believed it was an obligation and the country must be defended. $73 \%$ (73) were not satisfied. They said their children had been deprived of education and were now unemployable because they had no skills. Many families found that their children experienced stress and depression. The former child soldiers were argumentative, angry, and some had behavioural disorders and were pessimistic. Some 65 of these households stated that their children currently aged between 15 and 17 years old were with armed groups in support of the Taliban. 


\section{Baluchistan}

98 families were interviewed. Only 15\% (15) expressed satisfaction with the role their children had played in the Jihad and the defence of their country. 70\% (69) were not satisfied. $14 \%$ (14) families stated that they had encouraged their children to join armed groups as there was no other option for supporting the family economically. They were unhappy about the psychological effect of the fighting on their children. They said that the former child soldiers were aggressive, uncooperative and suffered from various disorders. They felt these children were talking too much and were demanding.

\section{Inside Afghanistan}

\section{Kandahar}

40 families were interviewed. 32\% (13) believed that during the war against the Soviet occupation, Jihad was an obligation. All Afghans had to fight against the invaders. Families willingly sent boys as young as fourteen or fifteen years old. If these young people had not fought, Afghanistan would have been lost, and Islam as a religion would have been suppressed.

$38 \%$ (15) regretted sending their children to war. They believed it was due to pressure from the local commanders and because there was no alternative occupation for the children. $15 \%$ (6) said it was due to economic problems as these children would then get clothes, money and food from the commanders.15\% (6) said they thought families had no influence over their children, the families could not stop them if they wanted to go. Armed groups were encouraging youth to join, and the children felt they had more status when they were armed and a were part of the militia.

Kabul Zone (Parwan, Logar, Ningarhar, Kapisa and Kabul)

58 families were interviewed. In Kabul itself few families supported the Jihad. This was possibly coming out of their experience since the defeat of the Najib government. Fighting between different factions in the city had destroyed more than half of the buildings and institutions.

Elsewhere in the zone, 50\% (30) families supported sending their children to the Jihad and $20 \%$ (11) regretted it. They complained about the lack discipline among the former child soldiers, their injuries and loss of limbs. These former child soldiers were badly behaved with neighbours and stubborn.

$20 \%$ (11) said they had sent their children to the war front for economic reasons. It was a way to earn a salary and support the family. Some political parties paid salaries to their Mujahedin and some commanders were providing assistance to their men. Later they also got an income from road tolls, punitive fees from disputing people and looting on the battlefield. 
$10 \%$ (6) said their children had gone without their permission. Many child soldiers were currently fighting alongside the Taliban against the opposition, and the families could not stop them. Commanders or Taliban authorities would also order a levy of one or two men per village to go to the war front and families were powerless to stop them.

\section{Bamiyan (Bamiyan and Ghor)}

60 families were interviewed. $35 \%$ (21) supported their children's role in the Jihad 'If it was not for the sacrifice of our children and youth we could not have thrown out the Soviets and we would not have been rewarded by God', 'Jihad is an obligation of any Muslim'.

$32 \%$ (19) did not support the war. They saw it as having caused destruction, illiteracy and disunity in the Afghan society. They said that children involved in the war had become aggressive, disabled and even addicts and thieves.

$21 \%$ (13) said the children had gone to fight because there were no other opportunities for them. Schools were destroyed, teachers were not available, and unemployment was very high. A child felt useless without a gun, which was both a means of defence and a status symbol. It showed that he belonged to a group where he might have some earnings. $12 \%$ (7) said they had no control over their youngsters. These young people were attracted by the commanders' invitation to join organised groups in the area. Often local commanders were forcing villagers to send one male per household to the armed groups. If this was refused then the villager had to leave the area or pay a ransom to the commander.

\section{Mazar}

165 families were interviewed. $31 \%$ (51) supported children going to war. They said they were proud of their children they had lost in this cause and did not regret it if they became disabled.

$39 \%$ (65) were unhappy that their children were taken by force. They had lost out on education and had been exposed to a culture of war, addiction and lack of discipline.

$22 \%$ (36) sent their children for economic reasons. They said there were no other opportunities. They had expected the war to be short, but now they regretted their mistake, knowing it could not be rectify.

$8 \%$ (13) said they had no influence. The commanders and group leaders took their children to the armed bases. Children who had no other opportunities would join up but there was no proper program for the children who grew wild and indulged themselves in all sorts of unacceptable activities. 


\subsubsection{Neighbours of former child soldiers}

\section{Refugee camps in NWFP and Baluchistan}

\section{North NWFP}

24 neighbouring families were interviewed. $3(13 \%)$ were satisfied and said the children who spent time with armed groups returned as good men. $3(13 \%)$ said the children had gone to join armed groups because they had relatives there. $4(17 \%)$ said children had to go to jihad on religious grounds. $8(33 \%)$ said that everyone had to serve their turn at the front because no one could be there all the time. $6(25 \%)$ of the children had to go to war because their families could not afford to pay 3,000/- Afghanis, which they would otherwise have had to pay to the commanders.

\section{Peshawar}

1 family neighbour of a war veteran in Nasirbagh was interviewed. 'I know my neighbour, Najib, from 1996. He was taken to be a soldier by force, from the roadside. Later he chose to stay on and became a petty officer until the army was fully dismantled in 1992 . He is now a refugee and living in Nasirbagh refugee camp since 1996. He is not normal now. He is sensitive and aggressive. He quarrels and screams at night. Obviously we are disturbed by him as we are often woken by his screaming during the night.'

\section{South NWFP}

22 neighbouring families were interviewed. $11(50 \%)$ said they were not happy about the behaviour of the returning child soldiers who had become aggressive with neighbours and quarrelsome with their family. $11(50 \%)$ commented that before they had gone to fight, the boys had been very calm but this was no longer so. These former child soldiers were no longer interested in other children. They were proud and their families did not stand up to them. Some of them were currently among the Taliban fighters in Afghanistan.

\section{Quetta}

23 neighbouring families were interviewed. $13(56 \%)$ were satisfied with the children's role in the jihad and their defence of Afghanistan against invaders. 10 (44\%) were not satisfied. They said the children involved in armed fighting, especially after 1992, had gained nothing. Their attitude was aggressive, they are sensitive to loud noise, suffered from anxiety and some have become addicts.

\section{Inside Afghanistan}

\section{Kandahar Zone}

20 neighbours of former child soldiers were interviewed. $10(50 \%)$ were satisfied, they believed that these youngsters who honestly went to jihad to defend their country, religion and honour, had made a great sacrifice, they were friendly toward the community and the community supported them. $5(25 \%)$ believed the youngsters belonged to the government and worked as secret intelligence agents, and had also gained positions in the 
ranks of the Mujahedin. They received money from the government to bribe people, and to disrupt attacks or to report about the movement of the Mujahedin.

$5(25 \%)$ believed the main reason for becoming a child soldier was economic, because many of them were later serving on the outposts along the roads, taking tributes from travellers. They were behaving arrogantly and were beating people not obeying them. Their neighbours were frightened of them. Some youngsters joined armed groups so that they could take revenge. Some were becoming addicted to smoking and committing adultery. Most were aged between 13-17 years old.

\section{$\mathrm{Kabul} / \mathrm{Jalalabad}$}

24 neighbours of former child soldiers were interviewed. 18 (75\%) were satisfied, they said that the youngsters volunteered to go to the war front along with elders, for the Jihad. The commanders encouraged them through Islamic preaching. These children were well behaved and the community did not have complaints about them. Many of the previous Mujahid youngsters were now working with the Taliban.

$6(25 \%)$ were not satisfied, they believed that many of the former child soldiers became arrogant and caused trouble at the front, however they were not a problem when they returned to their communities as the strong local tribal culture would not allow it.

\section{Bamiyan Zone}

53 neighbours were interviewed. $12(23 \%)$ were satisfied, saying that the former child soldiers had become mature, accountable and helpful in the community. $28(53 \%)$ complained about the children returning from the war. They claimed that war had made these children arrogant, demanding, thieves, gamblers, and addicted to smoking. The children were excited and sensitive and would resort to their guns, threatening others, at the smallest provocation. $9(17 \%)$ complained that commanders sent children to the war front without their parents' permission. Most of the children were between $12-18$ years old. Many were killed and those who returned were arrogant and dominating.4 ( 7\%) said that the children had been attracted by the weapons. For them, a gun was a toy, and a symbol of power and status. Often these children were oppressive and revengeful.

\section{Mazar}

44 neighbours of former child soldiers were interviewed. 18 (41\%) said that the children who had returned from the war fronts had changed. They were now more proud, arrogant, and often indifferent about the issues in the neighbourhood and with the elders. They were also interfering in matters not related to them. $13(30 \%)$ said that children had become soldiers because the schools were closed and there was a lack of opportunities for them. It gave them an identity. $8(18 \%)$ believed it was economic need which had pulled the children into paid army activities. They found it less strenuous to work for commanders than to work in the agricultural fields. They were robbing travellers and taking tributes from vehicles. Other youngsters who heard about this would willingly join them. $5(11 \%)$ said that the commanders forced children to join the men. 


\subsubsection{Mujahedin Commanders}

\section{In the refugee villages in NWFP and Baluchistan}

\section{Northern NWFP:}

110 commanders were interviewed. 68 (78\%) were positive about the impact of child soldiers participating in Jihad and defending their country. The people were encouraging young people to participate and be brave. The children learnt to be disciplined. They were full of energy and could stay longer in the bases than the adult fighters who would need to return home for periods of time. Children had given good service to the Jihad and had helped the wounded and martyred.

$5(4 \%)$ said that at the beginning of the Jihad the children's participation had been good, but later this was not so. 19 (17\%), said children's participation was not necessary. The children missed their education and many were killed. Also many were involved in looting.

The main duties for the child soldiers were to carry water for the base, cook and assist with laundry, collect fuel, take supplies to soldiers at watch-posts, clean weapons, and take the wounded for first aid or to hospitals in Pakistan if that was necessary.

Recruitment was voluntary in the beginning, when everyone was standing together against the invaders. As time passed the communities organised groups and fighting fronts. Each family had to send a man on a rotation basis. If the elders were not able to go themselves, the families would send their sons under 18 years old. Some young boys went by themselves without their parents' permission. When the morale was high and the armed Mujahedin were forcing the government troops back, the youngsters were eager to contribute and participate. There is no valid data on the number aged under 18 years old at each base or garrison. An estimate would be about 6 in a group 15 (i.e. 40\%).

Though most of the commanders were satisfied with having young men in their groups, they were aware of the problems this could create. The child soldiers were often not disciplined and got involved in petty crimes, addiction and looting. Sometimes disputes broke out between adult fighters trying to defend a particular child soldier. The handsome ones were appointed as bodyguards of the group leader and this gave him advantages over the others and caused jealousy.

\section{Peshawar:}

38 former commanders were interviewed. They said that the duties of child soldiers were to provide support, such as supplying water, cooking, and doing laundry, guarding and logistic activities. The child soldiers were eager to learn to use the weapons they saw, and many were very clever in receiving training. The trained child soldiers were always eager to participate in some armed action against government positions. Recruitment 
was voluntary, however there were sometimes tribal contribution to the zonal defence forces.

The clergy encouraged children to participate in Jihad through their preaching. The percentage of child soldiers in armed groups would vary, on average it was about $28 \%$. Children went to liberated areas and visited armed groups in their summer vacation. Often they had relatives in the groups. 19 (50\%) praised the role played by child soldiers in the Jihad and called it a good experience for them, but the other 19 (50\%) were opposed to having children among the armed forces. It required extra attention to guard them and train them to behave appropriately. Some child soldiers became addicted to naswar and cigarettes, though both were forbidden.

\section{Southern NWFP}

42 Mujahedin commanders were interviewed. They commented that child soldiers were often caught and killed by the enemy during a retreat, because they were not strong enough to carry their weapons at such a time.

\section{Quetta:}

31 Mujahedin commanders were interviewed. They said that child soldiers were providing logistical support and services. Children participated voluntarily, most probably in imitation of the role of adults. The children wanted a role in the Jihad. Their religion and preaching encouraged them to do this. 14 (45\%) believed the part child soldiers had played was positive. However the political parties were not compensating the families of those killed in the war. $8(26 \%)$ of commanders stated that addiction was not a major problem among the Mujahedin, though $6(19 \%)$ said that soldiers frequently used naswar and cigarettes. In a few groups hashish was also common.

\section{Inside Afghanistan}

\section{Kandahar}

8 Mujahedin commanders were interviewed. The Mujahedin were recruiting people aged between 13 and 50 years old. The youngsters were called chereeks, jawan and sometimes khumary, and were guided toward good behaviour. They were employed to cook, keep watch, and bring in supplies on donkeys and mules.. Some went to Pakistan during the winter and for military training. Many who had fled to the Mujahedin bases were the best of the school children who had been harassed by the communists. Many had become martyrs because they were excitable and lacked experience in warfare.

Some:chiltren came for economic reasons and for tribal affiliation. Addiction was not a problem at the beginning. Later on, as the war prolonged and the youngsters stayed on with no clear future, they turned to drugs as well as alcohol and adultery. They also got involved in dog-fighting, where the competitive nature of the sport had caused many killings. 
Commanders had differing attitudes toward the young child soldiers. While some treated them like their own children and looked after them, others would take advantage of these young boys and exposed them to sexual harassment. One commander said that he did not trust the young schoolboys who fled to him. He suspected them of being government spies and shot them.

\section{Kabul/Jalalabad}

10 Mujahedin commanders were interviewed. They said that about $20 \%$ of child soldiers were school children who had fled to Mujahedin bases. A few religious madrassa students had also come. There was not a single child coming from the house of the party leaders. They were all poor. Few were addicted to smoking. The child soldiers had been an essential source of the fighting force. They were employed for laundry, and kitchen services for the other Mujahedin. They were also commissioned for intelligence.

\section{Bamiyan}

20 Mujahedin commanders were interviewed. They said the children came to armed bases because of their obligation to the Jihad. Many were aged between 14-18 years old. In the beginning the Mujahedin were very dedicated and fought for the Jihad, but as the war became drawn out and inter-party fighting started, the nature of the services changed and there was less dedication to Islam. As the tribal militia and government agents increased their power, most child soldiers came addicted to smoking, gambling and alcohol, and their behaviour got worse. There was greater loss of life among them as they were more excitable, sensitive and lacked proper experience in battle. The lack of adequate health facilities meant that most of the children were not treated or assisted properly. Child soldiers were reportedly still fighting alongside the Taliban and their opposition groups, making up about $30 \%-40 \%$ of their strength.

\section{Mazar}

25 Mujahedin commanders were interviewed. $12(42 \%)$ said it was the duty of all Afghans to stand against the Soviet invasion and infidels. Afghans aged from $12-70$ participated in the Jihad and estimated that child soldiers made up about $25 \%-30 \%$ of the fighting force. These children had volunteered to participate in this popular movement.

$8(32 \%)$ said how genuine the Mujahedin struggle had been at the beginning. They fought for the sake of their country, religion and independence. But, over time, the communist government found ways into the ranks of the Mujahedin. They secretly recruited agents who introduced bad behaviour among the groups and made many of the young men and boys addicted to smoking cigarettes and hashish. These youngsters were then lured with offers of money, to join the ranks of the government units.

$5(20 \%)$ stated that after five or six years of fighting there was a turning point in the attitudes of the young Mujahedin. They lost their loyalty to the Jihad and began to indulge in criminal activities. Also many of the group leaders and commanders became soiled with criminal activities. Materialism captured their hearts. They began fighting among themselves and allied themselves to the government. They were looting the civilians and vehicles in many provinces. 


\subsubsection{Former Army Officers}

\section{In the refugee camps in NWFP and Baluchistan}

\section{Northern NWFP}

5 army officers were interviewed. They explained that soldiers were originally recruited in three categories. Obligatory recruits were called in by government offices in each district and province and were grouped and sent to various garrisons and regiments. The legal age was 22 years old before the Soviets invaded in 1979. This was then changed to 20. As the government was faced with lack of manpower in the regiments the recruitment age was brought down to 18 years. Forced recruitment was also imposed on students even as young as 16 and 14. A few who had good connections were appointed to logistic activities and were not sent to war. Reserve recruits were men who had had previous service in the army and were now called in again. Those aged between 20 and 40 years old were forcible called up. Some came for economic reasons as the government were paying monthly salaries to soldiers serving in professional activities. During active fighting they were given double pay. The third category were the volunteers.

The environment in the regiment was undesirable for child soldiers. Often the young boys were victims of sexual harassment by older soldiers or by their commanders. This was more likely to happen if they were good looking. There were no educational activities in the garrison. As the war dragged on, there was increasing inequality between the soldiers. Child soldiers were often not strong enough to carry weapons, and would be ridiculed and made fun of. This would demoralise them. The soldiers used naswar, cigarettes, hashish and alcohol. The army were providing these tranquillizers especially when they were at war.

\section{Peshawar}

80 former army officers were interviewed. They all confirmed that the original conscription age was 22 years old. When the government changed in April 1978 it was lowered to 20 and then 18 years old. With the arrival of the Red Army, children younger than 18 were caught and their documents changed to 18 and they were then conscripted. Each regiment and garrison had to complete their manpower quota.

$55(69 \%)$ of the army officers stated that the regiment and garrison were negative influences on young boys' characters. The programme was not designed for them and many problems were emerging. A lack of discipline and frustration in the army resulted in criminal activities including sexual harassment of new young recruits. The children were not able to escape the regiment and their sufferings and frustration drove them to use tranquillizers, this led to addiction. This problem had not existed in the army before the war.

The government created and encouraged tribal militia regiments where army rules were not applicable. These were contracted to fight alongside the army and capture Mujahedin controlled areas or defeat an assault by them. These garrisons had much deeper problems 
with regard to discipline and inter-group rivalries. There were moral and criminal activitis, looting and sexual crimes. However the army officers considered the role of the salaried young boys as positive. They took some training and learned some skills and brought a salary to their families.

\section{Southern NWFP}

4 army officers were interviewed. Most of the recruits under 18 were sent to tribal regiments and were forced into armed activities. On the other hand, many families in towns who feared the government, allowed their young boys to join the government personnel. The garrison environment was not conducive for these young men and it had a negative affect on their character.

\section{Quetta}

10 army officers were interviewed. Children in the government army were usually recruited by force. Houses were searched and young men captured and taken into the army. Children under the age of 18 were not used to living away from their families or taking care of themselves in the strange and alien environment of the garrison. The pressures, lack of a well defined program for them, and the unfriendly attitude of the elder soldiers and officers pushed these child soldiers into criminal activities and addiction. Economically, those in the front lines received concessions and medals and high salaries. Those in the back lines or at the garrison were paid normal monthly salaries and food rations.

\section{Inside Afghanistan}

\section{Kandahar}

8 army officers ranking from lieutenant to lieutenant general were interviewed. The official age for conscription was 18 years old, but the government was force-recruiting young school boys aged 16. Sometimes they even recruited the taller boys of 14 years. About $30 \%-40 \%$ of the manpower in a garrison were young soldiers. These child soldiers were organised into the police, intelligence and tribal garrisons. As the army was not set up for children, irregularities and crimes were taking place in the hostels. There was sexual exploitation and many became addicted to smoking. According to a former head of the human resource of the Afghan defence ministry, $80 \%$ of the child soldiers were addicts. When the Red Army arrived, Afghan soldiers began escaping from garrisons and the government started to fill their places with young, forced conscripts. Volunteer female guards and intelligence were recruited. Crimes, internal conflicts, thefts and some sexual abuse were problems in the regiments.

\section{Kabul/Jalalabad}

12 government army officers were interviewed. They said that child soldiers made up 5\% of the government affiliated soldiers, organised in tribal militias, revolutionary guard, self-defence etc. The loss of life among them was high because they were inexperienced, and people were not happy about this. Child soldiers were not disciplined and created 
problems in the battalions. Some were addicted to cigarettes, hashish and alcohol and many were sexually exploited by the commanders.

\section{Bamiyan}

7 former army officers were interviewed. They said that $15 \%-35 \%$ of the soldiers in their regiment were below 18 years old. There were no educational programs for them. They were employed in logistic work and later were sent to the war front. They were frightened and therefore easily turned to tranquillizers like cigarettes and hashish. Often they defected or surrendered to the opposition. One commander praised the role of child soldiers in the war. He said that they were called chereeks for encouragement and often they performed their duties in an outstanding manner.

\section{Mazar}

24 army officers were interviewed. 6 ( $25 \%$ ) stated that army regiments had employed young women around 20 year old. Their job was to assist the army in house-to-house searches and body searches of women travellers. They also performed intelligence activities in the communities.

$14(62 \%)$ stated that each army contingent had around $20 \%-25 \%$ of their force under the age of 18 . Their presence in the army caused a deterioration in army discipline and in combat ability. $3(12 \%)$ stated that most of the child soldiers were commissioned for intelligence activities. They usually sold arms and ammunition and stole these from others. Often they never returned from their missions.

In the beginning child soldiers were appointed to logistics and kitchen work but later were sent to the war lines. Excitement, lack of experience and the hasty actions of these boys were factors in their getting killed. They also became addicted to tranquillizers and drugs. As they needed money for drugs they would get into stealing and looting.

The handsome young boys were often sexually assaulted by those in their ranks and even their station commanders. The commanders in the north of the country were competing for pretty boys. Pretty boys were caught on the street and conscripted into their contingencies. Once they had been sexually abused, they were making other children follow them.

\subsubsection{Doctors}

\section{In the refugee camps in NWFP and Baluchistan}

\section{North NWFP:}

20 doctors were interviewed. They said that children went to war when they were frustrated with their families and wanted more freedom than they were being allowed, or because they were poor. Being single and having no family responsibilities meant that 
they were free to go and spend time with armed groups where they were fed and given clothes and footwear.

War experiences had been harsh for these child soldiers. Many had become frightened, quiet, depressed and sometimes aggressive, demanding and very argumentative. However, their new experiences had also made many of them braver and more objective in their life. They estimated that four out of every ten child soldier were on tranquillizers. These were also suffering from asthmatic and heart illnesses and from chronic diarrhoea. They estimated that 20\% of wounded soldiers were addicted to hashish, 60\% to nasmar and 20\% smoked cigarettes. Treatment for addicts was only effective while they were being medically supervised. Once they were back in their own environment they would revert to their addiction because of the pressures that had first lead to the addiction. They would advise addicts to live in a calm environment and avoid watching violent films.

\section{Peshawar:}

15 doctors were interviewed. $9(60 \%)$ stated that child soldiers were easily discouraged when a battle was lost, or if they saw their peers killed. They would also become revengeful. They estimated that about $60 \%$ were addicted to some form of tranquillizer. Often they did not recover because the doctor's orders were not followed. The doctors were powerless to prevent them from being taken back into the army. 6 (40\%) stated that those who had actively taken part wanted to continue fighting. $30 \%$ had behavioural and sensual disorders and would cry to themselves.

\section{South NWFP:}

3 doctors were interviewed. They stated that most of child soldiers suffered from psychological problems, $10 \%$ suffered from depression, sensual disorders and regrets. Often these people would seek tranquillizers and this would lead them to become addicted to smoking. It was hard to find an effective cure because the medicines were not effective.

\section{Quetta:}

Four doctors were interviewed. They said all soldiers became disheartened when they were wounded, but child soldiers would get psychologically depressed and hopeless. They would worry about their future and about how to cope with the pain from their wounds. They often sought tranquillizers, using cigarettes, hashish and opium. The doctors tried to prevent the relatives bringing these drugs into the hospital.

They said they did not have any way to safeguard children from going back to war. The police and government secret agents were following them. Doctors could not prevent the children being picked up again by them once they were discharged from hospital. 


\section{Inside Afghanistan}

\section{Kandahar}

9 doctors who had worked in government and military hospitals in Kandahar were interviewed. A third of all their patients were the child soldiers who were wounded in battle. They were depressed and worried about their survival and many lost their lives after surgery. One doctor said he had treated about 500 patients under 18 years old. Medical facilities were not adequate and about 20\% of the wounded died because of heavy bleeding. Amputations would disable them for life. Many were very sensitive, angry and frightened. They had lost their self-confidence and were traumatized. $30 \%$ to $40 \%$ of these patients were addicted to cigarettes and hashish because they were depressed and had no hope for the future. One doctor said that the authorities would take child soldiers who had recovered in the government hospitals, back to the warfronts.

\section{Kabul-Jalalabad}

6 doctors were interviewed. All said that child soldiers were among the war wounded they had treated. All were suffering from anxiety, depression and acute stress disorder. Though some were eager to go to war again, the majority did not want to. They were worried and hopeless. They had got caught up into the fighting because they were unawareness about its outcomes and injuries. They had lost their family members in the war. Some had joined armed forces because of the lack of educational opportunities, economic problems and the expectations of their communities. Each doctor recounted that he had treated between four and five thousand war victims.

\section{Bamiyan}

9 doctors were interviewed. During the war most of the wounded were youngsters between 15 and 20 years old. Most child soldiers returned to the war front after they recovered. One doctor recounted that a commander beat him when he was telling his young patients not to joint the armed groups again. $10 \%$ of the wounded were frightened depressed and sensitive and many became disabled. Many did not survive because of the lack of proper medical facilities and specialist doctors.

\section{Mazar}

21 doctors were interviewed. $19(90 \%)$ of them stated that the majority of the wounded were child soldiers. Most of these child soldiers suffered from mental disorders, fear, anxiety, suspicion, and aggression. They had often been victims of sexual harassment. Most were addicted to some form of tranquillizer. Only a few of the patients were willing to go back to their duties. Most wanted to escape. 


\subsubsection{Former Teachers}

\section{In the refugee camps in NWFP and Baluchistan}

\section{Northern NWFP:}

38 teachers were interviewed. Most children went to stay with the armed groups on Jihad during the summer. One reason was the burning heat of summer in the refugee camps. Children usually went to highlands and valleys where there was good water and had three or four months of the summer there. 27 (70\%) of teachers said children who went to the war zones were probably frightened, but liked the freedom and often went again. They liked to participate in jihad and wearing army jackets. They liked to learn to fight. But when they returned they usually could not concentrate in class. Sometimes they were proud and would not obey the teachers. Some became addicted to naswar and cigarettes.

$11(29 \%)$ of the teachers praised the character of the children who fought for Jihad and the experiences they had had. They believed these children would have seen the hardships of life and this would make them more realistic. It would make them respect their teachers and classmates.

\section{Peshawar:}

27 teachers were interviewed. $10(37 \%)$ of them believed that going into the army had been positive. It gave them organised army experiences and they had become more organised in their lives. Many later became good men and continued with their education. 17 (63\%) said that an estimated 20\% of students in high school and 10\% in secondary school were taken into the army by the government. The boys returning from the front were given concession like salaries and promotion by the party's youth wing. The strongest influence had been the political youth organisations which had been set up in schools. Once children had joined these, they would no longer pay attention to their studies or teachers. They would interfere in academic affairs. Students coming back from fighting were either very quiet and isolated or very aggressive, demanding and intolerant.

\section{South NWFP:}

5 teachers were interviewed. They believed one of the main reasons for going to war was the summer heat. Usually in $8^{\text {th }}$ to $10^{\text {th }}$ grades, about five students per class were going up to the highlands for four to five months. They would lose time out of their education and were becoming too politicised and partisan in their attitude. They were often very proud and sometimes argumentative.

\section{Quetta:}

9 teachers were interviewed. They said that about $40 \%$ of students went to Jihad every year. Most of the students in madrassa were taken into the army. These lost their time for studying, many become disorganised and did not like academic activities afterwards. The psychological impact on these children varies. Some of them become more mature and polite, while others became arrogant and demanding. 


\section{Inside Afghanistan}

\section{Kandahar}

20 teachers were interviewed. They stated that many students between 14 and 20 years old were encouraged to go to the war fronts and went for short periods of time. Some commanders did not make the appropriate arrangements for them and they were easily killed or wounded. Some of the students returning from the field behaved arrogantly and did not respect their teachers or the school rules.

Sometimes students brought handguns into their classrooms. In 1989 a student shot at his teacher, the teacher survived and the student was not punished because he was a member of the ruling party. One teacher said that many of the refugee students went to visit war fronts close to the border area. Some became arrogant afterwards, but for some it was a valuable experience and did not change their manners. In 1989 some students went to the war front in Ningarhar and 25 of them were killed.

\section{Kabul/Jalalabad}

4 teachers were interviewed in Ningarhar. They confirmed that both the government and the Mujahedin were recruiting young school students to go to the warfront for some months of the year. 20 students were sent to the war front from a school in Da-Sarark and only 5 returned. When they got back they were difficult and undisciplined and demanded free marks. In 1996 a Mujahedin party took all the students for a high school to assist in capturing Kabul. The school could do nothing to help these students except counsel them.

\section{Bamiyan}

Contact between teachers and students was severed in 1989 when all the schools were burnt. Those who went to war did not come back and the schools remained closed.

\section{Mazar}

38 teachers and school headmasters were interviewed. 11 (29\%) stated that after 1978 schools changed. The education level dropped considerably. Organisations for 'Youth Defending the Revolution' were created in schools and academic institutions. Many of the lazy, arrogant and uninterested students became members. These students no longer respected teachers or head teachers who were not members of the communist party. By the time they were 17 or 18 years old these young members of the organisation would have experienced two or three missions to the war lined. They were armed and had klashinkof automatic rifles as a symbol of pride, power and were the envy of other students. 7 (18\%) stated that once politics entered a school; and touched the young students, then there would be no more education and manners left the schuol. 13 (34\%) of the teachers stated that schools had unfortunately become the source of manpower reserves. Whenever the government wanted, they would pick boys who were physically well build and send them to the regiment. 


\section{Further Analysis and Discussion}

In this section of the report, three key issues have been selected for further analysis. These are: the reasons why children joined armed groups; the experiences and problems of being a child soldier; and the psychological impact of fighting on child soldiers. Qualitative data has been used from Part 3, together with further qualitative investigation of some of the questionnaire material. This was made possible because two of the researchers from SC-S were available during the preparation of this report to go through, and where necessary translate, the data they themselves had collected. However, the data has scope for further analysis, and would benefit from a deeper investigation, alongside research into relevant literature. The scope of this re-drafting of the report has not allowed for it here. These findings are therefore offered only as an introductory step.

\subsection{The reasons why children joined armed groups}

"Children may choose to join fighting forces voluntarily, for example if they feel that this is the best (or only) option available to them, or if they wish to fight for a cause. Sometimes children are motivated by revenge. Both forced and 'voluntary' recruitment should be seen in the wider context of the underlying factors that put children at risk of recruitment."

\section{Pressure from local commanders}

"Families or communities in or near the conflict zones may be required to provide a specific number of children. Families often make informed choices about giving their children up to armed forces - particularly if they are the local defence forces. Parents may have to choose between sending children or men, and deciding to hand over the children because they are economically less important to the household than men. Being seen to send more children off to fight can be a way of securing local popularity" 2

\footnotetext{
${ }^{1}$ McConnan, I and Uppard S ( 2001) Children Not Soldiers. Save the Children, page 36

2 Ibid, page 34
} 
Among the former child soldiers in Afghanistan, 138 (21\%) said they were forcefully recruited, making this the strongest single factor. If they had refused they would otherwise have had to pay compensation. Among the former child soldiers in refugee camps the percentage was only $6 \%$.

Often local commanders were forcing villagers to send one man per household to the armed groups. Otherwise a villager had to leave the area or pay a ransom to the commander. The official age for conscription was 18 years old, but the government was force- recruiting young schoolboys from 16. Sometimes they even recruited the taller boys of $14.15 \%-35 \%$ of the soldiers in a regiment could be below 18 .

Militia commander: Even today I have $50 \%$ of soldiers from 15 and above. The commanders can keep 1 to 3 children aged even 12 . Today I handed over command to my 12 year old nephew while I am on leave for 15 days. In wartime we forcefully recruited people on a tribe base. Age is not considered and even children are recruited. Children die more than adults as they are not afraid of bullets and are like animals (alwan) and unaware of consequences. Those who have land in Afghanistan are forced to send their children for jihad. If they refuse we will confiscate their crop. Also those who are unbearded are also recruited in emergency. When an emergency is over, then the children are sent back and the bearded are left. While recruiting we don't ask age, but look to see if they have beards.

\section{Poverty and family economic problems}

'For many children enlisting in fighting forces may be the only way they can survive, sheer desperation pushes them to join, a situation that recruiters frequently exploit, this 'push' factor is the denial of basic rights combines with the 'pull' factor of active targeting of children. ${ }^{3}$

Both among refugees and inside Afghanistan, poverty and economic necessity was the second most influential factor, with $24 \%$ of those from refugee camps and $17 \%$ inside Afghanistan giving it as their reason. Families said they had encouraged their children to join because there was no other option for supporting the family economically. Their children went to the war front to earn a salary and support the family. Some political parties paid salaries to their Mujahedin and some commanders were providing assistance to their men. By becoming child soldiers they could get clothes, money and food from the commanders. Later they also got an income from road tolls, punitive fees in disputes between people, and from looting

\footnotetext{
${ }^{3}$ McConnan, I and Uppard S (2001) Children Not Soldiers. Save the Children, page 37
} 
on the battlefield. There was not a single child coming from the house of the party leaders. They were all poor.

Community and family expectations - all must serve their turn

'Male adolescent are often expected to protect and provide for their family and community. During conflict this might include taking up arms, and traditional practices may be manipulated to maximise recruitment. ${ }^{4}$

9\% of the former child soldiers, both among the refugees in Pakistan and those living in Afghanistan, said they had been encouraged by their families and persuaded to take up arms. This may have been because they feared being criticised by others for not fighting. All were expected to serve their turn at the front because not everyone could be there all the time. As time passed the communities organized groups and fronts and each family had to send a man on a turn basis. Families would send their young boys even under eighteen if the older ones were unable to go themselves. Children went to liberated areas and visited armed groups in their summer vacation.

Former child soldier: I was living in Dir refugee camp. Principally every family had to send one person for Jihad. When my elder brother was martyred in Jihad I volunteered myself to participate. The commander refused to recruit me due to my young age but I insisted and thus joined him.

Former child soldier: When the interaction started I use to take part in hit and run operations at night, may be at the age of 10 . When we migrated to Pakistan, in order to replace my father, I used to spend three months in Jihad in each winter vacation. When I got married I gave up jihad.

Following relatives as role models, and the need for status

'When siblings, parents or other relatives are involved with the military, the child comes to regard this as the norm. Joining up then becomes a natural step to take, particularly if there is a strong ideological or religious element in the family's involvement. 5

Among the former child soldiers in refugee camps, $4 \%$ said it was for ethnic reasons, as there had been tribal competition for territorial control. Arms had been

\footnotetext{
${ }^{4}$ McConnan, I and Uppard S ( 2001) Children Not Soldiers. Save the Children, page 39

${ }^{5}$ Ibid, page 40
} 
freely available and the gun was not only for defence but also a symbol of their cultural pride and power. The children had gone to join armed groups because they had relatives there. $9 \%$ of former child soldiers in Afghanistan said they had joined because they had a relative already in the army. Children participated voluntarily, most probably in imitation of the adults. The children wanted a role in the Jihad. Their religion and preaching encouraged them. They saw a status for themselves as being armed and a part of the militia. A child felt useless without a gun, which was both a means of defensive and a status symbol, showing that he belonged to a group where he might have some earnings. The children were attracted to weapons. For them, a gun was a symbol of power and status. Often these children become oppressive and revengeful.

. Former child soldier: I was 13 years old when I joined. Because my relatives were in the Jihad, I went too. The people said then that as a Muslim, going to Jihad was good. ( Sawab $=$ do the will of God) My three uncles, my father my brother and some of my community were in Jihad. So I went. My responsibility was to serve the Mujahedin guests, bring bullets to the front line and also to fight myself. You start with bringing the bullets and then you take up the gun.

\section{Obligation to the Jihad}

'Political ideology or religious fundamentalism can seem to offer young people a way out of poverty, disenchantment or simply boredom. Military leaders often exploit such youthful idealism for their own purposes ${ }^{96}$

Among the former child soldiers in refugee camps, 50\% said it was to defend their country against invaders and for religious beliefs, whilst inside Afghanistan only 5\% gave this as their reason for becoming child soldiers. Families believed the children had to go to jihad on religious grounds and were satisfied with their role they had played in the defence of Afghanistan.

They thought the children who spent time with armed groups returned as good men. The communities were encouraging young people to participate and be brave. Recruitment was voluntary in the beginning when all were standing against invaders. Some young boys even went without their parents' permission. The clergy were encouraging them to

\footnotetext{
${ }^{6}$ McConnan, I and Uppard S ( 2001) Children Not Soldiers. Save the Children, page 39
} 
participate. Morale was high when the armed Mujahedin were forcing back the government troops, and the youngsters were eager to contribute and participate

Inside Afghanistan the Mujahedin were recruiting people between 13 and 50 years old for supporting the armed struggle. The youngsters were called chereeks, jawan and sometimes khumary. It was seen as an obligation to take part in the jihad.

Former child soldier One of the commanders use to talk about Jihad and I was inspired by him and accompanied him for Jihad. I use to cook bread for Mujahib in the beginning, sometimes I participated in fighting without permission of the commander.

Former child soldier: After grade 6 I left the school and went for the Jihad. I use to go without the permission of my father. Once he came after me and brought me back from the war front. I left my education incomplete. I fought for 6 years. Once I got a taste of Jihad I did not like school. I always rushed to get wounded, treated and again to fight.

\section{Lack of other opportunities}

'The family's economic situation may be very precarious compared to the economic offer made by armed forces. They lack alternatives for their future. They may not have opportunities for education or to sustain themselves. From an early age they may be familiar with armed actors who have been established in the region for a long time. "7

$1 \%$ of former child soldiers in the refugee camps had gone of their own free will and out of curiosity. 10\% from inside Afghanistan had said they volunteered. The motivation behind these decision are not given but significant adults said that children went to war when they were frustrated with their families and wanted more freedom or were poor. Being single and having no family responsibilities meant that they were free to go and spend time with armed groups where they were fed and given clothes and footwear.

There were often no alternative occupations for the children. Schools were destroyed, teachers were not available, and unemployment was very high. They needed to find an identity for themselves. They had gone to war due to a lack of educational opportunities, economic problems and social motivation. They had expected the war to be short. But now they regretted their mistake, which was difficult to rectify.

Former child soldier: I went to Jihad when I was 15 . I was in Grade 8 but when the Taliban bombed the schools then I joined Jihad, I belong to Hizb Islami. I went because I had no job. I wanted to go to Jihad. My father was the commander and most of my relatives were with the same party. 


\subsection{Experiences of being a child soldier}

"A child soldier is any person under 18 years of age who is part of any kind of regular or irregular force or armed group in any capacity including, but not limited to, cooks, porters, messengers and those accompanying such groups, other than purely as family members. This includes girls recruited for sexual purposes and forced marriages. It does not, therefore, only refer to a child who is carrying or has carried a gun." 8

\section{Loss of education and inappropriate learning environment}

There were no programmes designed for child soldiers or any educational activities in the garrison. These children had therefore lost educational opportunity and had been exposed to a culture of war. By being denied their schooling they had not acquired the skills they needed to secure proper jobs

Children who went to fight during the summer would lose time from their education and were becoming too politicised and partisan in their attitude. They were often very proud and sometimes argumentative. When they returned from fighting they usually could not concentrate in class. They were either very quiet and isolated or very aggressive, demanding and intolerant. Sometimes they were proud and would not obey the teachers. They had lost their time for studying, many become disorganised and did not like academic activities afterwards.

Some teachers praised the character of the children who had been on Jihad and the experiences they had had. They believed these children would have seen the hardships of life and had become more realistic and respectful of their teachers and classmates. Going into the army was positive because it gave them organised army experiences and this had helped them become more organised in their lives. Many of them later became good men and continued with their education.

Former child soldier: I was studying in Khalis Madrassa. After the exams were finished our group of 14 persons in which 12 were aged between 14-16 years old went to Jihad. One of our tribesmen became our commander. None of us came back to school.

\footnotetext{
${ }^{8}$ Cape Town Principles of Best Practice (1997) Adopted at the Symposium on the Prevention of Recruitment of Children into Armed Forces and on Demobilisation and Social Reintegration of Child Soldiers in Africa ( 27-30 April 1997)
} 


\section{Addiction to drugs}

The children were not able to escape the rigours of regimental life and were often frightened. Their sufferings and frustration often drove them to use tranquillizers, and this had led to addiction. Addiction had not been a problem in the army before the war. The soldiers used naswar, cigarettes, hashish and alcohol. These tranquillizers were being provided by the army, especially when they were at war. The need for money to buy drugs had got them into stealing and looting.

Former child soldier: Cigarettes, heroine and other drugs were regularly given to the Mujahedin because the weather was very cold and the Mujahedin were in very high places. The commander gave us hashish and other drugs to warm us and also to take away our fear and thoughts of self-preservation, so that we could throw ourselves fearlessly into the fighting.

\section{Problems caused by their physical immaturity}

The loss of life was high among child soldiers because they were excitable, hasty in their actions and inexperienced They were often caught and killed by the enemy during a retreat as they were not strong enough to carry their weapons at such a time. As the war dragged on, there was increasing inequality among the soldiers. Child soldiers who were physically not strong enough to carry weapons, would be ridiculed and made fun of, and this would demoralise them. As there was not adequate health facilities most were not given proper medical treatment.

Former child soldier: I was unable to climb mountains, one person pushed me from the back and another pulled me by the hand and that is how I climbed. The gun used to be carried by other soldiers, as it was very heavy for me.

Military commander: Child soldiers have most problems when they are on night guard, they would fall asleep and the commander would come and take away their guns, they were then punished before they could get their gun back. They might be put in a small room and denied them food before being given back their guns. We would help them by giving them first watch of the night. 


\section{Activities they took part in}

Child soldiers were essentially recruited to provide logistic and service support and were an important asset. They were carrying out such essential tasks as cooking, laundry, fetching water, collecting fuel, cleaning weapons, keeping watch, bringing supplies on donkeys and mules to soldiers at watch-posts, and taking the wounded for first aid or if necessary to hospitals in Pakistan.

Most of the government recruits under 18 years old were sent to tribal regiments and were forced into armed activities. The government created and encouraged tribal militia regiments where army rules were not applicable. These were contracted to fight alongside the army and capture Mujahedin controlled areas or defeat an assault by them. These garrisons had much deeper problems with regard to discipline and inter-group rivalries, moral and criminal disorders, lootings and sexual crimes.

Economically, there was more advantage in being at the front line. Those on the front lines received concessions, medals and high salaries. Those not at the front or at the garrison were paid normal monthly salaries and food rations.

Many child soldiers were recruited to be secret intelligence agents for the government, but they also gained positions in the ranks of the Mujahedin. They received money from the government to get information and to disrupt attacks, or to report about the movement of the Mujahedin. They were sent to Pakistan for training during the winter season and were commissioned to gather intelligence. Some sold arms and ammunition and stole these from others. Others would never returned from their missions, they would defect or surrender to the opposition.

Former child soldier: Once we went to Toorkhar to surrender to commander Ichar Mohd. We were about to reach the village when planes came and bombed us. We were 200 persons. We were on open ground. 50 of us were martyred. I saw my death from very near. The fighting was so severe that water came out of the ground. We were surrounded for one month. We could not get food in this period. We used to eat uncooked flour. We ate uncooked hunted birds. There was a situation that I got thirsty and did not have water. I drank mule urine to ease my thirst.

Former child soldier Once me and my other friend were assigned to take away some wire from an explosive ( nepam bomb) planted for enemies. By chance I waited at the bank of the river while my friend went to do the job. Before he reached there the explosive exploded and he split in pieces. I just got shocked for a while and then informed the other people. Blood came out of my lips due to the sever shock and anger. 


\section{Fighting skills}

$60 \%$ mujahedin commanders supported the role of the child soldiers in the Jihad. They said these children had given good service and had learnt to be disciplined. They were eager to learn to use the weapons they saw. Many were very clever in receiving training. When they were trained, they were eager to participate in armed action against government positions. They were full of energy and could therefore be kept longer at the bases than the adult fighters who needed to return home for periods of time.

Only $19 \%$ of former army officers were satisfied with the part the child soldiers had played. One army officer praised the role of child soldiers in the war. He said they were called chereeks for encouragement and often preformed their duties in an outstanding manner.

Militia commander: One of the boys, Abdullah, who was 16 years old, was so emotional and brave that, when he saw 25 persons lying dead and 1200 tanks coming, refused to run away and continued fighting alone, finally he was martyred there.

\section{Exposure to sexual harassment}

Army officers said it the lack of discipline and frustration in the army which had lead to criminal activities, including sexual harassment of new recruits. Often these young boys were victimised older soldiers or by their commanders, especially if they were good looking. The commanders in the north of the country were competing for pretty boys. Pretty boys were caught on the street and conscripted into their contingencies. Once they had been sexually abused, they were making other children follow them.

Mujahedin commanders said there were differing attitudes toward the young child soldiers. Some treated them like their own children and looked after them. They guided them toward good behaviour. Others took advantage of these young boys and exposed them to sexual harassment. One commander said that he did not trust young school boys who fled to him and considered them government spies and he shot them.

Social animator: Some of the big commanders kept beautiful children and sexually abused them. They forcefully married or disgraced these beautiful girls. In fact in every province sexual abuse had taken place. But when the mujahedin took over, then it increased. In Taliban and Masoon times extreme sexual violence took place. 
Former child soldier : Once I entered a house to get bread for my soldiers. When I entered the house I saw a fifteen-year-old girl with her shalwar at her feet. She was naked in the private parts. I asked her the reason for that. She told me that she was sexually abused by seven black arabs. I gave her my chaddar to cover herself and came out in an emotional state of mind. Four days later I saw arabs and killed seven of them. This is the first time I have confessed this truth. After that I used to hit their vehicles and killed them when I got a chance.

\section{Impact on their character}

When they returned to their communities, many child soldiers appeared to be proud, arrogant, and indifferent about their neighbourhood and their elders. They were stubborn and badly behaved and interfered in issues not related to them. However, some neighbours said there were no problems when they came back, as the strong local tribal culture would not allow this.

Child soldiers were not used to living away from their families or taking care of themselves in the strange and alien environment of the garrison. The pressures, lack of a well defined program for them, and the unfriendly attitude of the older soldiers and officers pushed these child soldiers toward a frustration which led to criminal activities and addiction.

At the front they became arrogant and caused trouble. If they needed money they were robbing travellers. Many of them were serving at the outposts along the roads and were taking tributes from travellers. Other youngsters who heard about what they were doing, then wanted to join them.

As there was no proper program for them they grew wild and indulged themselves in all sorts of unacceptable activities. They had become aggressive, drug addicts and thieves. Their indiscipline created problems in the battalions, as the army was not set up for child soldiers, and irregularities and crimes were taking place in the hostels.

The government recruited influential community leaders directly into the army. These were not trained military men and were less professional in their dealings. The effect on child soldiers was to make them badly behaved and addicted to smoking and alcohol. They also turned to adultery, and to dog-fighting which had resulted in many killings because of the competition to win. 
Some neighbours said that those child soldiers who honestly went to Jihad to defend their country, religion and honour, had made big sacrifices. They were friendly with the people and communities supported them. They volunteered to go to the war front for Jihad along with elders. These children were well behaved and the community did not have complaints about them. Many of the previous Mujahid youngsters are now working with the Taliban. They had become mature, accountable and helpful in the community.

\subsection{The psychological impact of fighting on child soldiers}

" Childhood trauma not only has the capacity to cause short-term symptoms, but it can also affect a child's personality development, interpersonal functioning, self-esteem, and coping ability throughout their lifespan. In addition, it can also have a deleterious effect on a child's cognitive capacity and moral development which may in turn influence educational achievement and a sense of social consciousness within their family or community. Even more concerning, is that generations of children who are growing up in violent situations may reach adulthood with the perception that violence is acceptable means of resolving ethnic, class, or religious difference."

\section{Increased Aggression}

Members of the community said that former child soldiers no longer behaved normally after serving with armed groups. They became proud and their families were not able to stand up to them. They were aggressive and quarrelsome, often treating their families harshly. They were angry, and had behaviour disorders. They were no longer interested in other children.

Neighbours reported former child soldiers as arrogant and beating people who would not obey them. The community were frightened of them. War had made these children arrogant, demanding, thieves, gamblers, and addicted to smoking. They were excitable and over reactive and would resort to their guns and threaten others at the smallest provocation.

Teachers observed that some of the students returning from the front behaved arrogantly and did not respect their teachers or the school rules. Sometimes students brought handguns into their classrooms. In 1989 a student shot at his teacher, the teacher survived but the student was not punished because he was a member of the ruling party.

\footnotetext{
${ }^{9}$ Gupta, L (1997) Psychosocial assessment of children exposed to war related violence in Kabul, UNICEF, page 1
} 
One teacher said that many of the students went to visit war fronts close to the border area. When they got back they were difficult and undisciplined and demanded free marks.

Former child soldier: At that time I was not good psychologically, every day I fought with my wife and children, I had no more energy to fight in the war. I met someone who runs a sports club and sometimes I go there now, I feel a little stronger. Some of my symptoms have eased up.

Former child soldier: I have psychological problems, I cannot concentrate, I don't remember things, I get violent and quarrels with people, I lose my senses and speak like I am mad. I am getting medicine.

\section{Depressions}

Many former child soldiers experienced stress and depression. They were troubled by their experiences, sometimes talking to themselves and were often pessimistic. Child soldiers, especially after 1992 had gained nothing. Their attitude was aggressive, they were sensitive to loud noise, suffer from anxiety and some had become addicts

Doctors said that the child soldiers they treated were often worried and hopeless. Many were addicted to smoking cigarettes and hashish as they were depressed and had no hope for the future. They had got engaged in the fighting because they were not awareness of its outcomes and injuries. They had lost their family members in the war. They were suffering from anxiety, depression and acute stress disorder. They worried about their survival and many were very sensitive, angry and frightened. They suffered from mental disorders, fear, anxiety and suspicion. They had lost their self-confidence and were often traumatized.

Former child soldier: We were ambushed with missiles. Hundreds of children of my own age were killed during the fighting, when I saw them I could no longer sleep well. I don't know how many I have killed, a lot.

Former child soldier : One day we went to Kunar for Jihad. After dinner and prayer the planes came and started bombarding. 200 young soldiers were killed , 8 were injured, and four died of their injuries and four of them were sent to Pakistan for treatment. It is a very bad memory for me and I remember it most of the time. I spent a lot of time, because of this, being very afraid. When I see planes I start shaking, even now I am afraid from these planes. I am not afraid of any weapons except when I hear an aeroplane. 


\section{CONCLUSIONS AND RECOMMENDATIONS}

This section returns to the objectives of this study. It discusses how effective the research has been in gathering the necessary data, and what are the key findings for each objective. It makes recommendations on possible next steps and what might be of value to the on-going work with former child soldiers. .

\subsection{How former child soldiers, now living in the refugee villages (camps) and in Afghanistan are psychologically affected by war}

Though a wide range of psychological problems were identified and presented in Part 3 of this report, the process of analysis and explanation of the categories has not been available. Thus this has been a very difficult area to work on. In Part 4, it has been selected for further analysis, using the qualitative comments collected from significant adults and presented in Part 3. 2 to 3. 6. Some material was also available from a selection of the original questionnaires. The two categories that had emerged from this analysis were aggression and depression.

Though the data reported that $58 \%$ of former child soldiers in refugee camps reported no specific changes in behaviour, the two SC-S researchers contributing to this report thought that all those they had interviewed showed signs of psychological disturbance resulting from their experiences. Even when former child soldiers reported that they had no psychological problems it was clear to these researchers that this was not the case and there was a discrepancy between what was said and the body language of their subjects.

Further research would benefit from more sensitive tools, such as those used by the UNICEF consultant Leila Gupta in her study Psychological Assessment of Children exposed to War Related Violence in Kabul ( 1997). In her recommendations she suggests a number of psychological interventions which would 'promote physical and psychological recovery and social reintegration of child victims of armed conflict' ( CRC Article 39)

However, there has been growing evidence through the 1980s and 1990s that a 'trauma' treatment approach is problernatic. In their book Mental Health (Children not Soldiers), (2001) McConnan, and Uppard emphasise the importance of context in shaping a person's experience of extreme suffering and dislocation, as well as their response to it. To use the blanket word 'trauma' has led to stereotyped responses, typically using individual or group counselling. Fieldwork evidence suggests that the chance to resume 'normal' life is the most important factor in the successful reintegration of former child soldiers. This means living in their own family and community and playing a useful economic role. The prevailing sense now is that the recovery of children affected by 
conflict must be considered in the context of the recovery of their communities. Any interventions to help children should therefore be rooted in a framework of rehabilitation and development that supports local efforts to rebuild social networks and the local economy.

5.2. How the Afghan children and the families deal with the experiences from the war, both in the refugee villages and inside Afghanistan

\section{No direct questions were asked on this objective and the only material in the original report was a brief section on 'treatments and remedies', which compared the use of traditional methods of treatment with modern medical services. Traditional remedies included herbal treatment, Ziarat (visiting sacred tombs) and Duaa and Taawez (amulets). Modern treatment included medication, counselling and psychiatric help.}

This area could benefit from being made the focus of further research, possibly built into the project now starting in Jallalabad. Leila Gupta in her study Psychological Assessment of Children exposed to War Related Violence in Kabul (1997) includes among her recommendations an in-depth qualitative assessment of 150 children and caretakers from her 1992-1996 survey. One of the objectives of this was to gain a deeper understanding of how Afghan people express their trauma and grief and traditional healing mechanisms to deal with it. She suggests that this could form the basis of a longitudinal study to follow up children and families over time, so as to learn more about the impact of chronic exposures to war related violence and the mediating factors that affect coping capacities.

5.3. The mechanisms and push factors involved in recruitment of child soldiers anu the extent of the problems in Afghanistan

The research produced considerable material on this issue, and it has been explored both in Part 3 and in Part 4. Part 3 data presented problems for further analysis, because it was not always clear what each of the categories meant or how the answers had been scored. 
It's data showed that forced recruitment was the most significant factor inside Afghanistan, whilst the obligation to fight for Jihad was the most significant among refugees. In both areas, poverty and family economic problems was the second most significant push factor. Another significant factor was the cultural orientation toward warfare and community expectation that all must serve their turn. Children followed relatives as role models and looked for status as a fighter.

To support the current work with reintegration of child soldiers, all these factors could be investigated in greater depth, in order to gain a deeper understanding of each and how they operated in different localities. Another area for further research would be the reasons which kept them in the armed forces. They may, for example, have been involved in killing a member of their own community and therefore unable to return. Alongside this, the reason why they stopped being a child soldier also needs deeper investigation. One former child soldier remarked that he stopped fighting once he married. Another spoke of his disillusioned with the Jihad, 'Sawab' was not what he thought. 'I am very unhappy because when I think of the result of the Jihad, right now I realise my enemies lie outside Afghanistan, who try to get two brothers to fight and kill each other, and now this is part of our culture'.

5.4. Recommended strategies and programmes to work with children who are psychologically affected by war.

This did not form part of the research that was carried out, though it had been in the original plan. Interviews were to have been held with 'experts' on child rights programming, specifically on programs and services. This could still be possible, as an extension of the research. Such initiatives as ARC (Action for the Rights of Children) have already established themselves as effective programmes for war-affected children, and SC-S are actively developing child rights programming. The initiative now starting in Jallalabad, on the reintegration of war affected adolescence in Nangarhar Province, is addressing the need for integration and rehabilitation through training, education, job-opportunities, recreational activities and psycho-social support. Whatever is undertaken here could incorporate a research strand which could evaluate strategies and programmes and their effectiveness.

The issues raised by McConnan, and Uppard in Mental Health (Children not Soldiers), (2001)are relevant to this objective. They argue that there is so far no evidence that large numbers of children have mental health problems that would benefit from specialist intervention. Such an assumption has tended to divert resources away from emergency aid and rehabilitation. Local initiatives to rebuild communities and restore a shared sense of dignity and purpose are more helpful than individual therapy and counselling. There is a need to address the broader social, emotional and economic problems facing children and adults who have witnessed the destruction of their families and communities. 


\section{Supportive texts}

Coalition to Stop the Use of Child Soldiers (2001) Global Report 2001.

Brett, R and McCallin, M (1996) Children: the invisible Soldiers. Radda Bamen (Swedish Save the Children)

Machel, G (1996) Impact of Armed Conflict on Children. Reprot of the expert on the Secretary General, Ms. Graca Machel, submitted pursuant to General Assembly Resolution 48/157

McConnan, I and Uppard S (2001) Children Not Soldiers. Save the Children

Cape Town Principles of Best Practice (1997) Adopted at the Symposium on the Prevention of Recruitment of Children into Armed Forces and on Demobilisation and Social Reintegration of Child Soldiers in Africa (27-30 April 1997)

Gupta, L (1997) Psychosocial assessment of children exposed to war related violence in Kabul, UNICEF. 